\title{
Comprehensive Review on the Use of Food Industry Wastewater as Substrates in Microbial Fuel Cells
}

\author{
Behzad Kanani* \\ Department of Food Science and Technology, Urmia University, Iran
}

Submission: May 05, 2021; Published: July 26, 2021

*Corresponding author: Behzad Kanani, Department of Food Science and Technology, Urmia University, Urmia, Iran

\section{Abstract}

Today, the world is facing climate change challenges with environmental protection being a top priority. Optimizing energy consumption due to its high cost and environment protection is a basic human demand. For industries, reduction in production costs is determinative to success. In this regard, Microbial fuel cell (MFC) is a unique promising technology with wastewater treatment and bioelectricity generation. The MFCs will help reduce energy consumption, curb the wastewater pollution, and standardize it for releasing into the environment. The food industry by producing high volumes of biomass with high organic pollution load are highly prone to use in MFCs as a substrate. Various food industry effluents have been tested, in real or synthetic form in the MFCs. Due to the improvements in the process and progress in novel configurations, better results have been increasingly obtained. Now, the MFC can be used in the industries individually or by integration with other technologies. In this review, the latest results from the use of food industry wastewater in MFCs along with effective process conditions are evaluated.

Keywords: Wastewater treatment; Food industry; Substrate; Power density; COD removal; Bio-energy

Highlights

a) Using real food industries wastewater as a substrate in MFC are evaluated.

b) Main wastewater components like pure synthetic wastewater are presented.

c) Municipal wastewater performance in MFCs is described.

d) Effect of wastewater sub-components in MFCs are investigated.

\section{Introduction}

Biotechnology is continuously innovating for creating and developing good ecosystems, transformation of pollutions, development of biodegradable material, development and modification of production processes and safe environmental disposal. In this regard, the waste management is one of the influential subjects of sustainable development. Biomass is the fourth biggest energy source worldwide and provides $14 \%$ of the world's energy. Extraction of bioenergy from biomass is novel area which has remained on a research scale. Turning biomass into bioenergy can be done through different biological methods. Bioelectrochemical (BE) systems are a promising technology through the Microbial Fuel Cells (MFC) whose major role is electricity generation through directly organic compounds oxidation.

MFC is a novel approach for the wastewater treatment and energy production simultaneously. Hence, two fundamental challenges of today's world can be addressed: available water and energy. The organic compounds in the wastewater are converted electricity through the electrogenic microorganisms. The main idea of using microbes to generate electricity was first introduced by Potter in 1911 [1]. Since then, more concepts and practical improvements have been achieved through the foundation of Cohen's 35-unit in 1931 [2]. Karube et al. [3] catalyst-related research began in the 1960s [3], followed by further work by Bennetto et al. [4] on kinetic mediators in the $80 \mathrm{~s}$ and 90 s, leading to the development of the term "analytical MFC" which is still in use. At the end of 1990 s, a series of discoveries showed that some special microorganisms can be used directly in fuel cells for the purpose of energy production without any involvement in hydrogen mediated procedures [5]. Approximately, through usual methods, more than 10 times energy in the form of carbon (C) compounds is needed to the organic substrate treatment in wastewater. On average, $1 \mathrm{~kg}$ of carbohydrates shows COD of $1.06 \mathrm{~kg}$ which can be converted into $4.41 \mathrm{kw} \mathrm{h}^{-1}$ or $13^{*} 10^{6}$ coulombs [6]. In the past two decades, there have been extensive developments 
in MFC technology including cost investment reduction, configuration improvement through novel, cheap and stable materials, comprehension of electron transferring mechanisms and their facilities, high-efficiency bio-electrocatalytic interfaces, substrates, microbial communities, biofilms, integrating with other technologies, bottlenecks and challenges identification, large-scale efficiency. With MFC efficiency improvement, the current density (Cd) of MFCs' is close to suitable level for practical operations.

Substrate plays an important role in the biological processes in providing the $\mathrm{C}$ source requirements $[7,8]$. he density of substrates and their chemical structure especially in real wastewater can affect the microbial population along with overall performance of MFC [8]. So far, many studies have been performed focusing on the variety of substrates and wastewaters. At the first step, researchers have focused on using a simple and pure substrate (C source) along with pure microbial culture followed by synthetic and real wastewater with different settings of MFC to examine the various aspects of MFCs. The possibility of electricity generation from complex substrates is a great achievement. The cheap cost of food industrial wastewaters along with biological benefits can make them a suitable choice for biological treatment. The food industry wastewaters mainly contain monomers of high molecular mass complex compounds of carbohydrates (the highest proportion), fatty acids, amino acids, nitrogen (N) compounds, sulfur (S) compounds, and phosphorus (P) compounds. The heavy metals can be effectively removed or recovered using MFC $[9,10]$. Also many studies have indicated the MFC capability for decreasing some azo dyes as a kind of contamination in dyed wastewater [11]. Based on the interaction between microbes and electrode, different systems have been developed that not only remove organic compounds, but also produce valuable materials from wastewater such as bio-flocculants, bio-plastics, biosurfactants, hydrogen, methane and many other compounds [12]. Nevertheless, a complex wastewater, which might cause problems for bacterial activity with a low conductivity, will be a major challenge in this path. Sometimes for efficiency improvement or removing obstacles in substrate availability especially for food industry wastewater, pre-treatment is required. For example, energy extraction from lignocellulosic based biomass has received much attention due to its accessibility and usability, as well as abundance [13].

MFCs are high potential technology with a great advantage of simultaneous wastewater treatment and bioenergy generation. This leads to changes in waste management, development of resource recovery technologies and development of diversified and efficiently energy. The MFC can be a special and attractive occasion for food industries. Now, given the high cost of energy for the food industries wastewater treatment around the world and the many challenges of standardizing wastewater for releasing, which is itself high cost and energy-intensive, MFCs can attract the attention of industries to find their place. As such, the MFCs can reduce the costs of production in industries. The energy generated can be used as part of the energy requirement for the production process, treatment process or other parts of the factory installations. This study has been conducted to help greatly the major steps of researchers towards the treatment efficiency improvement and the perfect industries for implementing by identification of wastewater and similar backgrounds. In mentioning the literature, the effort is not to merely report the figures and findings briefly, but to elaborate the important topics and special differences to provide better conclusion and comparison. Using these results, the food industries should be encouraged to invest widely in this field and help expand renewable energy, protect the environment, and reduce their own costs. It is hoped that this technology would be able to rapidly find its place in wastewater treatment plants or food industries.

\section{Main Components of Wastewater}

In general, most of the food industry wastewaters are based on C, N, S and P. Specifically, the C often constitutes the majority of pollutants, based on the nature of industrial activity, followed by other compounds. The behavior of these compounds in the MFCs as major components should be thoroughly investigated.

\section{Carbon resource}

$\mathrm{C}$ is one of the most significant organic compounds in food industrial wastewater. It provides favorable conditions for biological treatment for electricity generation. $\mathrm{C}$ exists in the wastewater in various forms. One of the main components of food industry is carbohydrates. It is clear that all monosaccharides of acidic hydrolysis of lignocellulosic material in the hydrolysis process can be used to generate electricity [14]. Some performances of MFCs with C resource as substrate are presented in Table 1. In this regard, the power was successfully generated from six hexoses, pentoses and sugar derivatives in an aircathode SC-MFC by a mixed culture and more than $80 \%$ reduction was achieved in COD [15]. Even so, with glucose loading rate of $1000 \mathrm{mg} \mathrm{l}^{-1} \mathrm{~d}^{-1}$, power density maximum (Pdm) of $4310 \mathrm{~mW} \mathrm{~m}^{-2}$ and CE of $81 \%$ were obtained in a DC-MFC [16]. Short chain volatile fatty acids can produce more electricity than long chain volatile fatty acids, due to their faster degradation than long chains. In this regard, acetate and propionate were the preferred options [17]. Regarding ethylene glycol, it was found that ethylene glycol did not have a negative effect even at high concentrations (2000ppm as the only C source). Of course, we could improve the MFC performance when ethylene glycol is used at the same concentration with glucose [18]. A continuous two-stage process with synthetic kitchen food waste and adding domestic wastewater as a balanced diluent was designed which was with hydrogen and volatile fatty acid generation in the first stage and electricity generation by MFC in the second stage. The MFC was operated using a volatile fatty acids-rich effluent from first stage that specifically contained acetic acid. The combined system could reduce the COD load by $90 \%$. The concentration of volatile fatty 
acids showed a descending trend over time. The CE of $46 \%$ and the $\mathrm{Cd}$ of $65.33 \mathrm{~mA} \mathrm{~m}^{-2}$ were obtained with a voltage of $148 \mathrm{mV}$ [19]. The appropriate effect of MFC on volatile fatty acids reduction was indicated. The methanol is not considered as a substrate and it is not applicable in this technology, but ethanol can be used [20]. The environmental and toxic effects of alcoholic sugars are still vague on other living organisms. Poly-alcohols cannot be completely metabolized and used by humans but can be used by MFC. As a byproduct in the ethanol fermentation process, they were used with 92\% Pd obtained within the range 1490-2650mW Table 1: MFCs Performance with Carbon Resources. $\mathrm{m}^{-2}$, with the following order galectitule $>$ ribitol $>$ xylitol $>$ arbitol $>$ sorbitol> mannitol respectively, and COD elimination was 71-92\% [21]. The treatment of recalcitrant $C$ source contaminant is very important. Hence, there are some ways for treatment performance improvement. In this regard, by engineering microbial consortia and using fermenter-exoelectrogen like Klebsiella pneumoniae can create a good situation in converting glycerol to lactate. Afterward, lactate can used by S. oneidensis as a C source to generate power [22].

\begin{tabular}{|c|c|c|c|c|c|c|c|c|c|c|}
\hline NO & Substrate & MFC Type & Inoculum & Anode & Cathode & $\begin{array}{c}\text { Voltage } \\
(\mathrm{mV})\end{array}$ & $\operatorname{Pd}\left(\mathrm{mW} \mathbf{m}^{2}\right)$ & $\begin{array}{l}\text { COD Re- } \\
\text { moval\% }\end{array}$ & CE\% & Ref \\
\hline 1 & Glucose & DC-MFC & $\begin{array}{l}\text { Mixed bacterial } \\
\text { culture }\end{array}$ & C cloth & C cloth & 390 & 2160 & 93 & 28 & [15] \\
\hline 2 & Glucose & DC-MFC & $\begin{array}{l}\text { Mixed bacterial } \\
\text { culture }\end{array}$ & C cloth & C cloth & 350 & 2090 & 93 & 23 & [15] \\
\hline 3 & Fructose & DC-MFC & $\begin{array}{l}\text { Mixed bacterial } \\
\text { culture }\end{array}$ & C cloth & C cloth & 310 & 1810 & 88 & 23 & [15] \\
\hline 4 & Fucose & DC-MFC & $\begin{array}{l}\text { Mixed bacterial } \\
\text { culture }\end{array}$ & C cloth & C cloth & 350 & 1760 & 84 & 34 & [15] \\
\hline 5 & Rhamnose & DC-MFC & $\begin{array}{l}\text { Mixed bacterial } \\
\text { culture }\end{array}$ & C cloth & C cloth & 270 & 1320 & 90 & 30 & [15] \\
\hline 6 & Mannose & DC-MFC & $\begin{array}{l}\text { Mixed bacterial } \\
\text { culture }\end{array}$ & C cloth & C cloth & 290 & 1240 & 88 & 25 & [15] \\
\hline 7 & Sucrose & SC-MFC & AS & C fiber & C cloth & NA & $1.79\left(\mathrm{~W} \mathrm{~m}^{-3}\right)$ & 94 & 4 & [33] \\
\hline 8 & Xylose & DC-MFC & $\begin{array}{l}\text { Mixed bacterial } \\
\text { culture }\end{array}$ & C cloth & C cloth & 380 & 2330 & 95 & 31 & [15] \\
\hline 9 & Arabinose & DC-MFC & $\begin{array}{l}\text { Mixed bacterial } \\
\text { culture }\end{array}$ & C cloth & C cloth & 260 & 2030 & 93 & 27 & [15] \\
\hline 10 & Ribose & DC-MFC & $\begin{array}{l}\text { Mixed bacterial } \\
\text { culture }\end{array}$ & C cloth & C cloth & 270 & 1520 & 86 & 30 & [15] \\
\hline 11 & Galacturonic acid & DC-MFC & $\begin{array}{l}\text { Mixed bacterial } \\
\text { culture }\end{array}$ & C cloth & C cloth & 330 & 1480 & 80 & 22 & [15] \\
\hline 12 & Glucuronic acid & DC-MFC & $\begin{array}{l}\text { Mixed bacterial } \\
\text { culture }\end{array}$ & C cloth & C cloth & 440 & 2770 & 89 & 24 & [15] \\
\hline 13 & Gluconic acid & DC-MFC & $\begin{array}{l}\text { Mixed bacterial } \\
\text { culture }\end{array}$ & C cloth & C cloth & 280 & 2050 & 93 & 30 & [15] \\
\hline 14 & Galactitol & $\begin{array}{l}\text { SC-MFC } \\
\text { Media- } \\
\text { tor-less }\end{array}$ & $\begin{array}{l}\text { Mixed bacterial } \\
\text { culture }\end{array}$ & C cloth & C cloth & 340 & 2650 & 90 & 13 & [21] \\
\hline 15 & Mannitol & $\begin{array}{l}\text { SC-MFC } \\
\text { Media- } \\
\text { tor-less }\end{array}$ & $\begin{array}{l}\text { Mixed bacterial } \\
\text { culture }\end{array}$ & C cloth & C cloth & 240 & 1490 & 91 & 19 & [21] \\
\hline 16 & Sorbitol & $\begin{array}{l}\text { SC-MFC } \\
\text { Media- } \\
\text { tor-less }\end{array}$ & $\begin{array}{l}\text { Mixed bacterial } \\
\text { culture }\end{array}$ & C cloth & C cloth & 260 & 1690 & 71 & 10 & [21] \\
\hline 17 & Arabitol & $\begin{array}{l}\text { SC-MFC } \\
\text { Media- } \\
\text { tor-less }\end{array}$ & $\begin{array}{l}\text { Mixed bacterial } \\
\text { culture }\end{array}$ & C cloth & C cloth & 260 & 2030 & 91 & 25 & [21] \\
\hline 18 & Ribitol & $\begin{array}{l}\text { SC-MFC } \\
\text { Media- } \\
\text { tor-less }\end{array}$ & $\begin{array}{l}\text { Mixed bacterial } \\
\text { culture }\end{array}$ & C cloth & C cloth & 320 & 2350 & 92 & 28 & [21] \\
\hline 19 & Xylitol & $\begin{array}{c}\text { SC-MFC } \\
\text { Media- } \\
\text { tor-less }\end{array}$ & $\begin{array}{l}\text { Mixed bacterial } \\
\text { culture }\end{array}$ & C cloth & C cloth & 290 & 2110 & 91 & 21 & [21] \\
\hline
\end{tabular}


International Journal of Environmental Sciences \& Natural Resources

\begin{tabular}{|c|c|c|c|c|c|c|c|c|c|c|}
\hline 20 & Glucose & $\begin{array}{l}\text { Stack- } \\
\text { MFCs }\end{array}$ & $\begin{array}{l}\text { Saccharomyces } \\
\text { cerevisiae }\end{array}$ & $\begin{array}{l}\text { Graphite } \\
\text { plate }\end{array}$ & $\begin{array}{l}\text { Graphite } \\
\text { plate }\end{array}$ & 3220 & 2003 & NA & 22 & {$[14]$} \\
\hline 21 & Glucose & $\begin{array}{l}\text { SC-MFC } \\
\text { Media- } \\
\text { tor-less }\end{array}$ & $\begin{array}{l}\text { Mixed microbial } \\
\text { solution }\end{array}$ & $\begin{array}{l}\text { Graphite } \\
\text { fiber felt }\end{array}$ & $\begin{array}{l}\text { Graphite } \\
\text { fiber felt }\end{array}$ & 351 & 218 & 98.8 & 26.2 & {$[27]$} \\
\hline 22 & Glucose & $\begin{array}{l}\text { SC-MFC } \\
\text { Media- } \\
\text { tor-less }\end{array}$ & AS & $\begin{array}{l}\text { Graphite } \\
\text { fiber felt }\end{array}$ & $\begin{array}{l}\text { Graphite } \\
\text { fiber felt }\end{array}$ & 508 & 456.8 & 94.3 & 55.4 & {$[27]$} \\
\hline 23 & Sucrose & $\begin{array}{c}\text { SC-MFC } \\
\text { Media- } \\
\text { tor-less }\end{array}$ & $\begin{array}{l}\text { Mixed microbial } \\
\text { solution }\end{array}$ & $\begin{array}{l}\text { Graphite } \\
\text { fiber felt }\end{array}$ & $\begin{array}{l}\text { Graphite } \\
\text { fiber felt }\end{array}$ & 305 & 164.6 & 93.7 & 20.3 & {$[27]$} \\
\hline 24 & Sucrose & $\begin{array}{c}\text { SC-MFC } \\
\text { Media- } \\
\text { tor-less }\end{array}$ & AS & $\begin{array}{l}\text { Graphite } \\
\text { fiber felt }\end{array}$ & $\begin{array}{l}\text { Graphite } \\
\text { fiber felt }\end{array}$ & 411 & 298.9 & 81.8 & 59.5 & {$[27]$} \\
\hline 25 & Ethylene glycol & DC-MFC & $\begin{array}{c}\text { Mixed anaerobic } \\
\text { consortia }\end{array}$ & $\begin{array}{l}\text { Unpolished } \\
\text { graphite }\end{array}$ & Pt sheet & NA & 5.72 & 97 & NA & [18] \\
\hline 26 & Glucose & DC-MFC & $\begin{array}{c}\text { Mixed anaerobic } \\
\text { consortia }\end{array}$ & $\begin{array}{l}\text { Unpolished } \\
\text { graphite }\end{array}$ & Pt sheet & NA & 2.47 & 92 & NA & [18] \\
\hline 27 & $\begin{array}{c}\text { Glucose +ethylene } \\
\text { glycol }\end{array}$ & DC-MFC & $\begin{array}{c}\text { Mixed anaerobic } \\
\text { consortia }\end{array}$ & $\begin{array}{l}\text { Unpolished } \\
\text { graphite }\end{array}$ & Pt sheet & NA & 5.26 & 94 & NA & [18] \\
\hline 28 & Acetate & $\begin{array}{l}\text { SC-MFC } \\
\text { Media- } \\
\text { tor-less }\end{array}$ & $\begin{array}{c}\text { Domestic waste- } \\
\text { water }\end{array}$ & $\begin{array}{l}\text { Toray C } \\
\text { paper }\end{array}$ & $\begin{array}{l}\text { C paper } \\
+\mathrm{Pt}\end{array}$ & 798 & 661 & 99 & 13.2 & {$[25]$} \\
\hline 29 & Butyrate & $\begin{array}{l}\text { SC-MFC } \\
\text { Media- } \\
\text { tor-less }\end{array}$ & $\begin{array}{c}\text { Domestic waste- } \\
\text { water }\end{array}$ & $\begin{array}{l}\text { Toray C } \\
\text { paper }\end{array}$ & $\begin{array}{l}\text { C paper } \\
+\mathrm{Pt}\end{array}$ & 795 & 349 & 98 & 7.8 & {$[25]$} \\
\hline 30 & Ethanol & DC-MFC & AS & $\begin{array}{l}\text { Porous C } \\
\text { paper }\end{array}$ & $\begin{array}{l}\text { Porous C } \\
\text { paper }\end{array}$ & 213 & 40 & NA & $42-61$ & {$[20]$} \\
\hline 31 & Ethanol & SC-MFC & $\begin{array}{c}\text { Sludge+ bacteria } \\
\text { from the DC- } \\
\text { MFC }\end{array}$ & $\begin{array}{l}\text { Porous C } \\
\text { paper }\end{array}$ & $\begin{array}{l}\text { Porous } \mathrm{C} \\
\text { paper }+\mathrm{Pt}\end{array}$ & 750 & 488 & NA & 11-May & {$[20]$} \\
\hline 32 & $\begin{array}{c}\text { Naphthalene+ } \\
\text { benzidine+2\% } \\
\mathrm{NaCl}\end{array}$ & SC-MFC & AS & C cloth & $\mathrm{C}$ cloth & 306 & 156.06 & 85 & NA & [29] \\
\hline 33 & Glycerol & SC-MFC & Bacillus subtilis & C cloth & $\begin{array}{c}\text { C cloth+4 } \\
\text { PTFE } \\
\text { diffusion } \\
\text { layers }\end{array}$ & 560 & $\begin{array}{c}0.06(\mathrm{~mW} \\
\left.\mathrm{cm}^{-2}\right)\end{array}$ & NA & 23.08 & {$[30]$} \\
\hline 34 & $\begin{array}{l}\text { Glycerol (pure, } \\
3.2 \mathrm{mg} \mathrm{l}^{-1} \text { ) }\end{array}$ & DC-MFC & AS & C paper & $\mathrm{C}$ cloth $+\mathrm{Pt}$ & 280 & 65.4 & 99 & 34.1 & [31] \\
\hline
\end{tabular}

Depending on the inoculum, the $\mathrm{C}$ source of either fermentable (glucose) or non-fermentable C (acetate) can be very important. The output power is a function of wastewater rigidity based on a Monod-type relationship with a half-saturation constant of Ks [23]. The energy conversion efficiency and potential efficiency in MFCs was investigated. The methane was only detected in glucose-fed MFC, which shows that acetoclastic methanogens are pushed out of the competition by the anolyte respiring bacteria. Unlike a high biomass density, the anode respiring bacteria density and electron donor concentration were very low causing a large reduction of potential efficiency with low $\mathrm{Cd}$. This condition leads to the slow kinetics for electrons transferring into the anode and the large loss because of substrate concentration gradient in the anode biofilm. The energy conversion efficiency was obtained $42 \%$ and $3 \%$ with acetate and glucose respectively. Potential efficiency of $6 \%$ with the Pdm of $9.8 \mathrm{~mW} \mathrm{~m}^{-2}$ with low current for glucose were obtained. As such, the main reason for the reduction of potential efficiency and Pd in glucose is the presence of non-electrogenic bacteria with high-concentration in anode biofilms and low electron donor concentration. In contrast, potential efficiency of $59 \%$ for acetate with high current and Pdm of $360 \mathrm{~mW} \mathrm{~m}^{-2}$ [24]biomass, residual organic compounds, $\mathrm{H} 2$, and $\mathrm{CH} 4$ gas. The comparison of the two donors allowed us to objectively evaluate the diversion of electron flow to nonelectricity sinks for fermentable donors, leading to different behaviors in energy-conversion efficiency (ECE. Note that unlike acetoclastic methanogens, the anolyte respiring bacteria could not out-compete $\mathrm{H}_{2}$-oxidizing methanogens. Therefore, with use of organic complexes as fuel, the control of methane production is so important and the CE can significantly improve. Totally, many of complex sugars cannot be used by common exoelectrogenes such as Shewanella, Geobacter. Specially, S. oneidensis was 
unsuccessful in power generating from glycerol as a microbial consortium due to lack of compounds as the transporters. Thus, the selection of microbial species based on the type of substrate is very important.

The output power is a function of the substrate density which can be well described with saturation kinetics, although the Pdm was different from the circuit load [25]. The colloidal particles and organic complexes in fermented wastewater not only reduce the $\mathrm{Pd}$, but also has important roles as rate-limiting parameters in the steady output power. Pd reduction is mainly due to the high IR of the complex substrate. In this regard, a Pd $1,884 \mathrm{~mW} \mathrm{~m}^{-3}$ from real fermented wastewater (obtained from coffee bean processing wastewater), while Pd of $3664 \mathrm{~mW} \mathrm{~m}^{-3}$ was obtained from acetate with the same OLR. The Pd reached $2981 \mathrm{~mW} \mathrm{~m}^{-3}$ by doubling the OLR. At result, the effect of complexity and OLR is clear [26]. On the other hand, based on the CE, the MFC performance can be raised with increasing substrate complexity which is due to the fact that some species can use products derived from other species during the process of biodegradation of complex wastewater [27]. The Pd with butyrate as a substrate was obtained $66 \%$ lower than acetate with the same open circuit voltage (OCV). The CE and energy recovery values were $(31-10 \%, 3-7 \%)$ and $(15-8 \%, 2-5 \%)$ for acetate and butyrate respectively suggesting a significant loss of electrons and energy in processes except electricity generations [25].

Operational parameters are the determining factors in system performance. Adding mediators in MFC with can have a significant effect on performance. For example, When toluene as a xenobiotic contaminated was used with pyocyanin (as a mediator), there was 3.64-time increment in the Pdm from 4.69 to $21.7 \mathrm{~mW} \mathrm{~m}^{-2}$ and 13 -time increment in CE from $0.83 \%$ to $11.62 \%$ than when toluene was used alone. Adding pyocyanin improved electricity production significantly by system impedance reduction, electron density increase, and reducing the IR (from 500 to 100) [28]. The MFCs performance in naphthalene and benzidine treatment increased by $344.77 \%$ in relation to power generation when the redox riboflavin mediator $(30 \mu \mathrm{M})$ was added externally [29]. The salinity is an effective method in treatment of a naphthalene and benzidine mixture. The optimal salinity was $2.0 \%$ and with salt concentration of $5 \%$, where the performance was significantly improved. The $\mathrm{pH}$ can play an important role in treatment efficiency. The investigation during glycerol degradation indicates that the electricity generation during long time was stable under neutral toward alkaline conditions. The electrochemical activity increased via adding $\mathrm{pH}$ from 7, 8 and 9, where $\mathrm{pH} 7$ was the most suitable $\mathrm{pH}$ for stable current generation [30]. The identification of optimum concentration is very important. With the increase in glycerol concentrate higher than optimum, the Pd can remain, but CE and COD removal decreased [31]. Due to effect of type of substrate and its concentration on microbial community changes, a special attention was paid to the evolutionary stages of the anaerobic inoculum via replacing glycerol with glucose as a substrate for reaching a steady MFC efficiency with suitable Pd. Even at high concentrations of glycerol, the adaptability of Anaerobic Sludge (AS) with the use of glucose is an appropriate method for maintaining the MFC's stable performance [31]. Identification of optimum temperature is very important. The performance of the system was desirable at $40^{\circ} \mathrm{C}$ (compared to $30^{\circ} \mathrm{C}$ and $50^{\circ} \mathrm{C}$ ) where a Pdm of $292.60 \mathrm{~mW} \mathrm{~m}^{-2}$, COD elimination of $90 \%$, and naphthalene and benzidine biodegradation of $100 \%$ were obtained. The biological degradation of naphthalene, benzidine, COD, Pdm, and CE at $40^{\circ} \mathrm{C}$ were $178.78 \%, 196.29 \%$, $215.78 \%, 185.07 \mathrm{~mW} \mathrm{~m}^{-2}$, and $120.53 \%$ better respectively compared to the initial temperature $\left(30^{\circ} \mathrm{C}\right)$. However, these cases dropped sharply when the operation temperature reached $50{ }^{\circ} \mathrm{C}$ [29]. Generally, the best temperature is dependent on species of microbial community.

Since the integration is one of the suitable methods for increasing the MFC application, a two-phase process of dark fermentation linked with a DC-MFC and the raw glycerol was used. After fermentation, $20 \%$ of organic compounds was removed by of hydrogen gas production. The fermentation effluent with COD of $7610 \mathrm{mg} \mathrm{l}^{-1}$ used as feedstock for MFC and Pd of $92 \mathrm{~mW} \mathrm{~m}^{-2}$, COD elimination of $50 \%$, and CE of $14 \%$ were obtained. When the fermentation effluents were diluted by $50 \%$, CE was only $27 \%$. Higher concentrations of the substrate led to further electron loss due to other chemical, physical, and microbial reactions [32].

\section{Nitrogen resource}

One important part of organic compounds in domestic wastewater, food processing, and industrial wastewater is protein as a source of nitrogen $(\mathrm{N})$. Ammonia, ammonium, nitrite, and nitrate are the most important $\mathrm{N}$ forms with nitrate being one of the most problematic compounds in wastewater in particular. To remove the $\mathrm{N}$ from wastewater, nitrification and denitrification are well-known methods. Some performances of MFCs with $\mathrm{N}$ resource as substrate are presented in Table 2 . In this regard, the R-group in amino acids plays an effective role in power generation from protein. The R-group of some amino acids include alanine (non-polar amino acids), serine (polar amino acids), asparagine with a side neutral-charged side chain and histidine, lysine and arginine with positively-charged side chain, as well as aspartic acid and glutamic acid with a negative charge. The Pd generation is as follows (L-Serine $>$ L-Arginine $>$ L-Histidine $>$ L-Glutamic acid $>$ L-Aspartic acid $>$ L-Asparagine $>$ L-lysine $>$ DL-Alanine) [34]. In MFCs, the hydrophilic and acidic parts can easily be degraded in comparison to the neutral sections. In addition, the aromatic compounds in the hydrophilic section can preferably be removed more than non-aromatic compounds. The compounds such as tryptophan-protein in all parts and aromatic proteins in neutral part of hydrophilic and hydrophobic can easily be removed. Further, the MFC can easily hydrolyze and biodegrade the hydrophobic amide- 1 proteins and aliphatic components. The carboxylic and alcoholic groups in hydrophobic acid and hydrophobic neutral and transphilic acid increase due to the 
hydrolysis and fermentation of high molecular organic compounds [35]. Bovine serum albumin is a model of compounds which is characterized by a high weight and high water solubility molecule structure; peptone is a complex mix of various proteins and meatpackaging wastewater generally contains blood, meat, fat tissue, meat extracts and animal abdominal contents with COD. The highest Pd of $354 \mathrm{~mW} \mathrm{~m}^{-2}$ from bovine (1100 $\left.\mathrm{mg} \mathrm{l}^{-1}\right), 269 \mathrm{~mW} \mathrm{~m}^{-2}$ from peptone $\left(300 \mathrm{mg} \mathrm{l}^{-1}\right.$ ), and $80 \mathrm{~mW} \mathrm{~m}^{-2}$ from meat-packaging wastewater (1420 $\mathrm{mg} \mathrm{COD} \mathrm{l}^{-1}$ ) were obtained. With salinity and adding $\left(300 \mathrm{mg} \mathrm{l}^{-1} \mathrm{NaCl}\right)$ to increase the conductivity in meat Table 2: MFCs Performance with Nitrogen Resources. packaging wastewater, the Pd reach increased by $33 \%$. The protein elimination was obtained more than $94 \%$ for all substrates. Also, a COD elimination of $87 \%$ was achieved for meat packaging wastewater [36]. The concentration of substrate is effective on internal resistance (IR) and totally on power generation. The $\mathrm{Pdm}$ reached $19 \mathrm{~mW} \mathrm{~m}^{-2}$ with cysteine concentration of $385 \mathrm{mg}$ $\mathrm{l}^{-1}$ where IR was about 700-1000. The Pdm increased by $39 \mathrm{~mW}$ $\mathrm{m}^{-2}$ when cysteine concentration reached $770 \mathrm{mg} \mathrm{l}^{-1}$ where IR was about 493 [37].

\begin{tabular}{|c|c|c|c|c|c|c|c|c|c|}
\hline NO & Substrate & MFC Type & Anode & Cathode & $\operatorname{Pd}\left(\mathrm{mW} \mathbf{m}^{2}\right)$ & $\begin{array}{l}\text { COD Re- } \\
\text { moval\% }\end{array}$ & $\begin{array}{l}\text { N Remov- } \\
\text { al\% }\end{array}$ & CE\% & Ref \\
\hline \multirow{2}{*}{1} & \multirow{2}{*}{$\begin{array}{c}\text { Synthetic } \\
\text { wastewater }\end{array}$} & \multirow{2}{*}{ Coupled MFC } & $\begin{array}{l}\text { Graphite } \\
\text { felts }\end{array}$ & $\begin{array}{l}\text { Graphite felts - oxic } \\
\text {-biocathode }\end{array}$ & $14\left(\mathrm{~W} \mathrm{~m}^{-3}\right)$ & 98.8 & 97.4 & NA & [39] \\
\hline & & & $\begin{array}{l}\text { Graphite } \\
\text { felts }\end{array}$ & $\begin{array}{l}\text { Graphite felts - anox- } \\
\text { ic-biocathode }\end{array}$ & $7.2\left(\mathrm{~W} \mathrm{~m}^{-3}\right)$ & & & NA & \\
\hline 3 & $\begin{array}{l}\text { University of } \\
\text { Connecticut } \\
\text { wastewater } \\
\text { (3.5 mg l-1 of } \\
\text { DO) }\end{array}$ & $\begin{array}{l}\text { Short-cut nitrifica- } \\
\text { tion and autotro- } \\
\text { phic denitrifica- } \\
\text { tion MFC }\end{array}$ & C brushes & C cloth & 294.9 & NA & 99.9 & 2.41 & {$[41]$} \\
\hline 4 & $\begin{array}{c}\text { Wastewater } \\
\text { Treatment } \\
\text { Plant }\end{array}$ & SC-MFC & $C$ felt & $C$ felt & 88 & $97 \%$ & 96 & 43 & {$[46]$} \\
\hline
\end{tabular}

Using the nitrate as a cathodic electron acceptor is a good way for $\mathrm{N}$ removal. The removal of $\mathrm{N}$ mainly depends on the sequential nitrification and denitrification in wastewater treatment. The nitrification and denitrification were obtained in the half-cell by completing the cathodic nitrification process through special aeration. The denitrification efficiency increased by reduction of dissolved oxygen in a cathodic chamber of membrane-aerated MFC [38]. The nitrate can be denitrified electrochemically by oxidizing the ammonium in to the nitrate in a coupled oxic-biocathode MFC and anoxic-biocathode MFC. Most of COD is eliminated at the two MFCs anodes. The oxic-biocathode is responsible for nitrate oxidization and anoxic-biocathode is responsible for nitrate denitrification [39]. Another coupled MFC was configured, composed of a nitrifying sulfide elimination MFC and a denitrifying sulfide elimination MFC. The favorable sulfur $(\mathrm{S}) / \mathrm{N}$ ratio was three. Total $\mathrm{N}$ elimination of $58.7 \%$ and S production of 27.4 $33.3 \%$ were obtained. The entrance of nitrifiers and electroactive oxic microorganisms from the oxic-cathode in the anoxic-cathode was successful in $\mathrm{N}$ elimination [40]. Next, a short-cut nitrification and autotrophic denitrification MFC was developed, which unlike biological nutrient removal processes, had a simplified operation, reduced operational time, reduced aeration cost, saved C sources, and reached energy-positive situation. In the cathode of MFC with Short-cut nitrification, ammonium was mainly reduced to nitrite instead of nitrate (nitrite to nitrate ratio: 3 ). The nitrite reduced to $\mathrm{N}$ gas through autotrophic denitrification via electrons generated from the anode chamber. It generates $0.007 \mathrm{kWh} \mathrm{m}^{-3}$ of net electricity which is the self-sustained energy-positive and with an excellent potential for removing nutrients [41]. For developing a high-rate denitrifying, the cathode $\mathrm{COD} / \mathrm{NO}_{3}-\mathrm{N}$ ratio was effective on OCV and nitrate elimination significantly. The heterotrophic conditions in the cathode did not change the energy production. The optimal $\mathrm{pH}$ for denitrification was 7. In this regard, in MFC cathode, a high-rate denitrification was obtained by cow manure and soil. The best $\mathrm{NO}_{3}-\mathrm{N}$ removal rate of $7.1 \mathrm{~kg} \mathrm{NO}_{3}-\mathrm{N} \mathrm{m}^{-3}$ net cathodic chamber $\mathrm{d}^{-1}$ was obtained in the $7.31 \mathrm{COD} / \mathrm{NO}_{3}-\mathrm{N}$ ratio with a $\mathrm{Cd}$ of $190 \mathrm{~mA} \mathrm{~m}^{-2}$, a Pd of $31.92 \mathrm{~mW} \mathrm{~m}^{-2}$ and CE of 9.7. Reduction in OCV and $\mathrm{NO}_{3}-\mathrm{N}$ elimination rates were obtained at $\mathrm{COD} / \mathrm{NO}_{3}-\mathrm{N}$ ratio $>12$ and $<7$. The overall $\mathrm{CE}$ was low in this case which could have been related to the anode unfavorable metabolic products and the high organic level content of cathode [42].

An anaerobic sequencing batch reactor as a pre-treatment was integrated with MFC for increasing ability to oxidize insoluble, polymeric, and complex organics. This system can increase hydrolytic-acidogenic conversion, power recovery, and $\mathrm{C}$ and $\mathrm{N}$ removal. In this regard, through the sewage and groundwater, soluble organics and volatile fatty acids contents increased by $52 \%$ and $120 \%$ with sewage pretreatment, respectively. The optimum Pd of $7.1 \mathrm{~W} \mathrm{~m} \mathrm{~m}^{-3}$ and $\mathrm{Cd}$ of $45.88 \mathrm{~A} \mathrm{~m}^{-3}$ were obtained indicating $8 \%$ and $10 \%$ improvements compared to without pretreated sewage. As compared to without pre-treatment system, $217 \%$ higher for C elimination and $136 \%$ higher for $\mathrm{N}$ elimination were obtained with integrated system [43]. In addition, $\mathrm{N}$ elimination in cathode can be catalyzed by anaerobic ammoniumoxidizing bacteria (anammox) along with denitrifiers and nitrifiers. Anammox produces dinitrogen gas as a final product by employing nitrite as the electron acceptor [44]. In this regard, a loop MFC was configured which included a denitrifying organics/ 
sulfide elimination MFC and a nitrification chamber. High total organic carbon/ sulfide ratio in effluent was successful to elemental S recovery and electron generation. Entrance of oxygen into the cathode could enhance $\mathrm{N}$ elimination and output power but prevented elemental S recovery. The total organic carbon/ sulfide ratio of 4.69 and cathodic DO of $4.2 \mathrm{mg} \mathrm{l}^{-1}$ were favorable. In this situation, $100 \%$ of total organic carbon, $100 \%$ of sulfide, and $82.6 \%$ of total $\mathrm{N}$ were eliminated with $\mathrm{S}$ recovery of $35.1 \%$ and CE of 53\%. Further, prevailing denitrifiers, nitrifiers, and anammox also took part in $\mathrm{N}$ elimination in the cathode [45].

\section{Sulfur resource}

The S compounds such as sulfide and sulfate are harmful and toxic to human health, as well as corrosive with unpleasant odor. These compounds in found some food industrial wastewater such as sugar and alcohol. Sulfate cannot be removed directly by the MFC as it is an electron acceptor. Thus, the sulfate-reducing bacteria (heterotrophic bacteria that uses organic compounds as $C$ and energy sources) could convert the sulfate to sulfide in an anaerobic medium [47]. Then, MFC uses the sulfide oxidizing bacteria (they are autotrophic, so they need minerals electron acceptor such as nitrate, for oxidation of sulfide) and it oxidizes the sulfide to $S^{0}[48]$. There is no possibility for simultaneous removal of sulfide and organic compounds if there is lack of nitrate or other electron acceptors in wastewaters. While adding the electron acceptors is not an appropriate and eco-friendly option [49]. As such, for the reaction of sulfide oxidation, the anodic level can act as an acceptor for electrons [50]. ulfide and sulfate are removed with electricity generation simultaneously using the MFC with the anodic biofilm SRB (sulfate reducing bacteria) + SOB (sulfide oxidizing bacteria) and anode as an electron acceptor [51]. Thus, this biological reactor can remove sulfide, nitrate, and organic compounds simultaneously [52-55]. It was also found that bacteria associated with $\mathrm{S}$ and anaerobic fermentation bacteria interact with each other [56]. The initial concentration of sulfide has a positive relationship with the bioelectricity production. Given that, the anode potential diminishes due to increase in sulfide as it has a low recovery potential [56]. Some performances of MFCs with S resource as substrate are presented in Table 3.

Table 3: MFCs Performance with Sulfur Resources.

\begin{tabular}{|c|c|c|c|c|c|c|c|c|c|c|c|}
\hline NO & Substrate & MFC Type & Inoculum & Anode & Cathode & $\begin{array}{c}\operatorname{Pd}(\mathbf{m W} \\
\left.\mathbf{m}^{-2}\right)\end{array}$ & $\begin{array}{c}\text { Voltage } \\
\text { (mV) }\end{array}$ & $\begin{array}{l}\text { COD Re- } \\
\text { moval\% }\end{array}$ & $\begin{array}{c}\text { S Re- } \\
\text { moval } \\
\%\end{array}$ & CE \% & Ref \\
\hline 1 & $\begin{array}{l}\text { Artificial } \\
\text { wastewater } \\
\text { (containing } \\
\text { lactate and } \\
\text { sulfate) }\end{array}$ & $\begin{array}{l}\text { Cylindrical } \\
\text { DC-MFC }\end{array}$ & $\mathrm{SRB}+\mathrm{SOB}$ & C felt & C cloth & 62 & 730 & NA & NA & $\mathrm{Na}$ & [50] \\
\hline 4 & $\begin{array}{c}\text { Artificial } \\
\text { wastewater }\end{array}$ & SC-MFC & $\begin{array}{l}\text { Desulfovib- } \\
\text { rio desulfu- } \\
\text { ricans }\end{array}$ & $\begin{array}{l}\text { High } \\
\text { surface area } \\
\text { activated C } \\
\text { cloth }\end{array}$ & $\begin{array}{l}\text { C cloth } \\
\text { +Nafion } \\
\text { ionomer }\end{array}$ & 0.51 & NA & NA & $\begin{array}{c}99 \% \\
\text { (sulfate) }\end{array}$ & NA & [62] \\
\hline 5 & $\begin{array}{c}\text { Artificial } \\
\text { wastewater } \\
\left(60 \mathrm{mg} \mathrm{l}^{-1} \text { of }\right. \\
\text { sulfide, } 800 \mathrm{mg} \\
\left.\mathrm{l}^{-1} \text { of COD }\right)\end{array}$ & $\begin{array}{l}\text { Anaerobic } \\
\text { baffled } \\
\text { stacking } \\
\text { MFC }\end{array}$ & AS & $\begin{array}{l}\text { C fiber felt } \\
\text { and graph- } \\
\text { ite granules }\end{array}$ & C paper & $200-270$ & 2582 & 73.8 & 81.2 & NA & [56] \\
\hline 6 & $\begin{array}{c}\text { Artificial } \\
\text { wastewater }\end{array}$ & $\begin{array}{l}\text { H-type } \\
\text { cylindrical } \\
\text { DC-MFCs }\end{array}$ & $\begin{array}{l}\text { Anaerobic } \\
\text { granular } \\
\text { sludge }\end{array}$ & C-fiber-felt & C-fiber-felt & 396.1 & NA & 31.7 & 88.5 & 11.4 & [60] \\
\hline 7 & $\begin{array}{c}\text { Artificial } \\
\text { wastewater }\end{array}$ & $\begin{array}{c}\text { H-type } \\
\text { cylindrical } \\
\text { DC-MFCs }\end{array}$ & $\begin{array}{l}\text { Anaerobic } \\
\text { granular } \\
\text { sludge }\end{array}$ & $\begin{array}{c}\mathrm{TiO}_{2}+\mathrm{C}-\mathrm{fi}- \\
\text { ber-felt }\end{array}$ & C-fiber-felt & 607.8 & NA & 56.9 & 94.4 & 13.2 & [60] \\
\hline 9 & $\begin{array}{c}\text { Artificial } \\
\text { wastewater }\end{array}$ & $\begin{array}{c}\text { H-type } \\
\text { cylindrical } \\
\text { DC-MFCs }\end{array}$ & $\begin{array}{l}\text { Anaerobic } \\
\text { granular } \\
\text { sludge }\end{array}$ & $\begin{array}{c}\mathrm{Fe}_{2} \mathrm{O}_{3}+\mathrm{C} \text {-fi- } \\
\text { ber-felt }\end{array}$ & C-fiber-felt & 537.6 & NA & 55.2 & 91.4 & 12.2 & [60] \\
\hline 10 & $\begin{array}{l}\text { Sulfate-rich } \\
\text { wastewater }\end{array}$ & DC-MFC & $\begin{array}{l}\text { Pretreated } \\
\quad \text { AS }\end{array}$ & $\begin{array}{l}\text { Biotic } \\
\text { anode- } \\
\text { Non-cat- } \\
\text { alyzed } \\
\text { graphite }\end{array}$ & $\begin{array}{l}\text { Abiotic } \\
\text { cathode- } \\
\text { Non-cat- } \\
\text { alyzed } \\
\text { graphite }\end{array}$ & 240 & 498 & 58 & 56 & NA & [63] \\
\hline 11 & $\begin{array}{c}\text { Artificial } \\
\text { wastewater+ } \\
\text { lactate, }\end{array}$ & DC-MFC & SRB & C rod & $\begin{array}{c}\text { Pressed } \\
\text { activated } \\
\text { C+ graph- } \\
\text { ite rod }\end{array}$ & 349 & $\approx 0.7$ & 77.5 & 93.2 & NA & [59] \\
\hline
\end{tabular}


MFCs can remove the sulfate significantly. This ability can be further increased using several methods. Particularly, using graphite as an electrode, the sulfate removal was obtained 99.84\% [57]. In comparison to glucose, sulfide was alternatively used as an electron donor and the Pdm was obtained $401 \mathrm{~mW} \mathrm{~m}^{-2}$ at level of $100 \mathrm{mg} \mathrm{l}^{-1}$ with removal of $64 \%$ which was more than twice that of the case with glucose in a mediator-less DC-MFC [58]. Elsewhere, the sulfide and COD removals increased when HRT increased from 24 to $60 \mathrm{~h}$, but electricity generation was not increased as the electron donor was inadequate at the end of the reactor. The sulfide was mainly oxidized to $\mathrm{S}$ and sulfate [56]. Adding electron donor can have a major effect on microbial communities causing enhanced sulfate reduction and electricity generation. The share of each phylum in the microbial community is affected by the electron donor. In this regard, lactate has proved to be more effective than glucose. The analyses indicated that electron donors especially lactate have a great effect on sulfatereducing, S-reducing and sulfur-oxidizing bacteria growth [59]. On the other hand, modified anodes can increase sulfide removal. They can provide more active surface for bacterial adhesion by enhancing density of biomass. C-fiber-felt anodes were modified by the Nano-layers of $\mathrm{TiO}_{2}$ and $\mathrm{Fe}_{2} \mathrm{O}_{3}$ in the vertical direction. Compared to MFC with C-fiber-felt anode, Pdm was improved by 1.53 and 1.36 times for $\mathrm{MFC}-\mathrm{TiO}_{2}$ and $\mathrm{MFC}-\mathrm{Fe}_{2} \mathrm{O}_{3}$, respectively and sulfide removal efficiency and total organic $\mathrm{C}$ was increased after 48 hours [60]. The $\mathrm{pH}$ of 8 as is more effective compared to acidic and neutral condition. Alkalinity and salinity can increase the power generation by sulfate reducing bacteria. The Pdm of $1188 \mathrm{~mW} \mathrm{~m}^{-3}$ was obtained at $6 \mathrm{~g} \mathrm{l}^{-1}$ of $\mathrm{NaCl}$ concentration [61].

\section{Phosphorus resource}

Table 4: MFCs Performance with Phosphorus Resources.

\begin{tabular}{|c|c|c|c|c|c|c|c|c|c|c|c|}
\hline NO & Substrate & MFC Type & Inoculum & Anode & Cathode & $\begin{array}{c}\text { Pd }(\mathbf{m W} \\
\left.\mathbf{m}^{2}\right)\end{array}$ & $\begin{array}{c}\text { Voltage } \\
\text { mV }\end{array}$ & $\begin{array}{l}\text { COD } \\
\text { Remov- } \\
\text { al\% }\end{array}$ & $\begin{array}{c}\text { P Re- } \\
\text { moval\% }\end{array}$ & C E\% & Ref \\
\hline 1 & $\begin{array}{l}\text { Synthetic waste- } \\
\text { water ( } 3.5 \mathrm{mg} \mathrm{l}^{-1} \\
\text { of DO) }\end{array}$ & $\begin{array}{l}\text { Tubular DC- } \\
\text { MFC }\end{array}$ & $\begin{array}{l}\text { AS and } \\
\text { aerobic } \\
\text { sludge }\end{array}$ & C paper & $\mathrm{C}$ cloth $+\mathrm{Pt}$ & 530 & 521 & 81 & $84-97$ & 52.48 & [64] \\
\hline 2 & $\begin{array}{l}\text { Synthetic waste- } \\
\text { water (DO } 2 \mathrm{mg} \mathrm{l}^{-1} \\
\text { of DO) }\end{array}$ & $\begin{array}{c}\text { Tubular DC- } \\
\text { MFC }\end{array}$ & $\begin{array}{l}\text { AS and } \\
\text { aerobic } \\
\text { sludge }\end{array}$ & C paper & $\mathrm{C}$ cloth $+\mathrm{Pt}$ & 303 & 178 & 77.3 & $84-97$ & 23.9 & [64] \\
\hline 3 & $\begin{array}{l}\text { Swine waste- } \\
\text { water }\end{array}$ & SC-MFC & - & $C$ felt & $\begin{array}{l}\text { C paper } \\
+\mathrm{Pt} / \mathrm{C}\end{array}$ & $\begin{array}{l}2.3(\mathrm{~W} \\
\left.\mathrm{m}^{-2}\right)\end{array}$ & 300 & 91 & $82 \%$ & 47 & [66] \\
\hline
\end{tabular}

$\mathrm{P}$ is known as one of the main pollutants of food wastewater. $\mathrm{P}$ has also a valuable aspect in wastewater, because as a fertilizer it is a nutrient for plant growth. $\mathrm{P}$ as a natural resource is subject to shortage, so recovery of $\mathrm{P}$ from wastewater has become an important issue. Accordingly, the MFCs are offered in this regard and it can be a brilliant way of removing and recovering P. In MFCs, cathodic dissolved oxygen is effective on performance due to the loss of the electron acceptor. The drop of power generation is due to the decline in the cathodic dissolved oxygen. With dissolved oxygen reduction, $\mathrm{Pd}$ and CE decline sharply. In addition, following chemical precipitation, a large amount (about $80 \%$ ) of total $\mathrm{P}$ was eliminated, by microbial absorption (17-4\%) and by the sediments contained phosphate, carbonate and hydroxylate. The COD was first eliminated in the anode (> 70\%) followed by in the cathode $(<5 \%)$. In anaerobic anode, phosphorus-accumulating bacteria absorbed a large part of COD in polyhydroxybutyrate form. Along with entrance of this effluent to cathode with aerobic or oxygenpoor condition, polyhydroxybutyrate is used by phosphorusaccumulating bacteria as the $\mathrm{C}$ source. However, most of $\mathrm{N}$ can be removed (more than $85 \%$ ) when cathodic dissolved oxygen was reduced to low levels [64]. Some MFCs performance with P resource as substrate are presented in Table 4. The constructed wetlands MFC (CW-MFC) showed an increase of capacity in immobilized $\mathrm{P}$ with the removal rate of total $\mathrm{P}$ and reactivity $\mathrm{P}$ of $85-86 \%$ and $89-90 \%$ respectively from swine slurry. An alum sludge was used while providing a concurrent up flow-down flow system and the Pdm increased by $70 \%$ and reached $0.268 \mathrm{~W} \mathrm{~m}^{-3}$ (compared to $0.168 \mathrm{~W} \mathrm{~m}^{-3}$ for up-flow system). However, the COD removal efficiency dropped to $64 \%$, compared to $80 \%$ which was achieved by a constant up-flow system [65].

Regarding P recovery, MFCs are able to recover phosphate from the digested wastewater sludge by precipitating in the cathode in the form of struvite $\left(\mathrm{MgNH}_{4} \mathrm{PO}_{4} \cdot 6 \mathrm{H}_{2} \mathrm{O}\right)$. The result of production in suspended solid form (instead of the solution form) indicates that $\mathrm{P}$ in the suspended solid form is first dissolved, and then it is precipitated on the cathode [66]. The orthophosphate can be obtained from iron phosphate $\left(\mathrm{FePO}_{4}\right)$ available in digested wastewater sludge by reaction with $\mathrm{Mg}^{+2}$ and $\mathrm{NH}_{4}{ }^{+}$. The process efficiency was achieved to be up to $82 \%$ or $600 \mathrm{mg} \mathrm{l}^{-1}$. The crystalline fertilizer was analyzed and it was found that the compound is about $90 \%$ accurate and there are no toxic metals such as arsenic, cadmium, lead, or chromium [67]. In another study, $70-82 \%$ of phosphorous was eliminated and some struvite formed where the amount of $\mathrm{P}$ in these was about $4.6-27 \%$ of the influent [66]. 
Integrating the MFC considerably increases the organics, N and $\mathrm{P}$ removal in CWs. The optimal operating conditions for COD, $\mathrm{NH}_{3}-\mathrm{N}, \mathrm{N}$ and $\mathrm{P}$ removal are very different from each other and are affected by several factors. HRT is the most important factor via about $50 \%$. Generally, dissolved oxygen level in the cathode and effluent reflux ratio are significant for pollutant removal and external resistance is the most effective factor for power generation [68]. In addition, ferrous ion, ferric ion, and ferric hydroxide, as metabolic intermediates are useful for phosphate elimination [69]. In another integration, the CW-MFC with pyrite can produce effluents with a stable $\mathrm{pH}$ and low sulfate level. It increased power generation 19-28.4\% more than CW-MFC without pyrite. Also, nitrate and total $\mathrm{P}$ removal efficiencies in the CWMFC with pyrite were $15 \%$ greater than CW-MFC without pyrite and obtained as $70.1 \%$ and $91.2 \%$, respectively [70]. A pyritebased CW-MFC can be useful. Pyrite $\left(\mathrm{FeS}_{2}\right)$ is an abundant sulfide mineral including $\mathrm{Fe}$ and $\mathrm{S}$. By increasing $\mathrm{N}$ removal through autotrophic denitrification, pyrite is a suitable feedstock for CWs
[71]. According to the results, the success of this technology in the removal and recovery of valuable phosphorus can be seen, which is still needed to enhance the efficiency with further studies.

\section{Food Industry Wastewater}

The food industry wastewaters are generally based on the main components of the wastewater. Nevertheless, the real wastewaters can be used in this technology. A real wastewater is a collection of components where each of them can have a special effect on the process individually. Some of these pollutants can inhibit microbial process and some of them can facilitate it. As such, evaluation of real wastewater as a complex collection in the MFSs is a proper way to improve and achieve clear results. The results of MFCs performance with some different food industrial wastewaters content as substrate are presented in Table 5 . Some important food industry wastewaters, which have been investigated in studies, are described.

Table 5: MFCs Performance with Food Industry Wastewater.

\begin{tabular}{|c|c|c|c|c|c|c|c|c|c|c|}
\hline NO & Substrate & MFC Type & Anode & Cathode & Inoculum & $\begin{array}{c}\text { Pd }(m W \\
\left.m^{-2}\right)\end{array}$ & $\begin{array}{c}\text { Voltage } \\
(\mathrm{mV})\end{array}$ & $\begin{array}{l}\text { COD Re- } \\
\text { moval\% }\end{array}$ & CE\% & Ref \\
\hline \multirow[t]{2}{*}{1} & \multirow{2}{*}{$\begin{array}{l}\text { Composite } \\
\text { vegetable } \\
\text { waste }\end{array}$} & \multirow{2}{*}{$\begin{array}{l}\text { Media- } \\
\text { tor-less } \\
\text { SC-MFC }\end{array}$} & \multirow{2}{*}{$\begin{array}{l}\text { Graphite } \\
\text { plate }\end{array}$} & \multirow{2}{*}{$\begin{array}{l}\text { Graphite } \\
\text { plate }\end{array}$} & $\begin{array}{l}\text { Anaerobic } \\
\text { mixed }\end{array}$ & \multirow[t]{2}{*}{57.38} & \multirow[t]{2}{*}{250} & \multirow[t]{2}{*}{62.86} & \multirow[t]{2}{*}{ NA } & \multirow[t]{2}{*}{ [136] } \\
\hline & & & & & consortia & & & & & \\
\hline 2 & $\begin{array}{c}\text { Composite } \\
\text { canteen-based } \\
\text { food waste }\end{array}$ & $\begin{array}{l}\text { Solid phase } \\
\text { SC-MFC }\end{array}$ & $\begin{array}{l}\text { Graphite } \\
\text { plate }\end{array}$ & $\begin{array}{l}\text { Graphite } \\
\text { plate }\end{array}$ & NA & 170.81 & 463 & 76 & NA & [137] \\
\hline 3 & Food wastes & SC-MFC & C cloth & $\begin{array}{l}\text { C cloth } \\
+\mathrm{Pt}\end{array}$ & AS & $5.6\left(\mathrm{~W} \mathrm{~m}^{-3}\right)$ & 510 & 90.3 & NA & [35] \\
\hline 4 & $\begin{array}{l}\text { Food process- } \\
\text { ing wastewa- } \\
\text { ter }\end{array}$ & DC-MFC & $\begin{array}{l}\text { Graphic } \\
\text { sheets }\end{array}$ & $\begin{array}{l}\text { Graphic } \\
\text { sheets }\end{array}$ & Sludge & 230 & 422 & 86 & 21 & [127] \\
\hline 5 & $\begin{array}{l}\text { Food waste } \\
\text { leachate }\end{array}$ & DC-MFC & $\mathrm{C}$ & $\mathrm{C}$ & $\begin{array}{l}\text { Anaerobic } \\
\text { sludge }\end{array}$ & $\begin{array}{c}15.14(\mathrm{~W} \\
\left.\mathrm{m}^{-3}\right)\end{array}$ & 1120 & 90 & NA & [77] \\
\hline 6 & $\begin{array}{l}\text { Food waste } \\
\text { leachate }\end{array}$ & SC-MFC & $C$ felt & $\begin{array}{l}\text { Gas } \\
\text { diffusion } \\
+\mathrm{Pt}\end{array}$ & $\begin{array}{l}\text { collected from } \\
\text { wastewater } \\
\text { plant }\end{array}$ & $1.86\left(\mathrm{~W} \mathrm{~m}^{-3}\right)$ & 250 & 95.4 & 11.07 & [138] \\
\hline 7 & $\begin{array}{l}\text { Dairy waste- } \\
\text { water }\end{array}$ & $\begin{array}{l}\text { Media- } \\
\text { tor-less } \\
\text { DC-MFC }\end{array}$ & $\begin{array}{l}\text { Graphite } \\
\text { plate }\end{array}$ & $\begin{array}{l}\text { Graphite } \\
\text { plate }\end{array}$ & Activated sludge & 621.13 & 856 & 90.46 & 37.16 & [139] \\
\hline 8 & $\begin{array}{l}\text { Dairy waste- } \\
\text { water }\end{array}$ & $\begin{array}{l}\text { SC-MFC (pH } \\
\text { initially ad- } \\
\text { justed to 9) }\end{array}$ & C cloth & C cloth & $\begin{array}{c}\text { Escherichia coli } \\
-\mathrm{K}-12\end{array}$ & $1.05\left(\mathrm{~W} \mathrm{~m}^{-2}\right)$ & 654 & 95.45 & 67.53 & [140] \\
\hline 9 & $\begin{array}{l}\text { Dairy waste- } \\
\text { water }\end{array}$ & DC-MFC & Copper & Copper & $\begin{array}{l}\text { Anaerobic and } \\
\text { facultative mi- } \\
\text { crobes in dairy } \\
\text { wastewater }\end{array}$ & NA & 644 & 92.2 & NA & [141] \\
\hline 10 & $\begin{array}{l}\text { Dairy waste- } \\
\text { water }\end{array}$ & $\begin{array}{l}\text { Up-flow tu- } \\
\text { bular MFC }\end{array}$ & C cloth & $\begin{array}{l}\text { C cloth } \\
+\mathrm{Pt}\end{array}$ & $\begin{array}{c}\text { Shewanella } \\
\text { oneidensis and } \\
\text { Clostridium } \\
\text { butyricum }\end{array}$ & $2.4\left(\mathrm{~W} \mathrm{~m}^{-3}\right)$ & 490 & 96 & $4.40 \%$ & [80] \\
\hline 11 & $\begin{array}{l}\text { Dairy waste- } \\
\text { water }\end{array}$ & SC-MFC & C cloth & $\begin{array}{l}\text { C cloth } \\
+\mathrm{Pt}\end{array}$ & $\begin{array}{l}\text { Shewanella } \\
\text { oneidensis and } \\
\text { Clostridium } \\
\text { butyricum. }\end{array}$ & $0.5\left(\mathrm{~W} \mathrm{~m}^{-3}\right)$ & 616 & 95.5 & 1 & [142] \\
\hline
\end{tabular}


International Journal of Environmental Sciences \& Natural Resources

\begin{tabular}{|c|c|c|c|c|c|c|c|c|c|c|}
\hline 12 & $\begin{array}{l}\text { Whey (from } \\
\text { sterile filtra- } \\
\text { tion) }\end{array}$ & DC-MFC & $\begin{array}{l}\text { Plain C } \\
\text { paper }\end{array}$ & $\begin{array}{c}\text { C cloth }+ \\
\text { Pt }\end{array}$ & AS & 46 & NA & 94 & 11.3 & [143] \\
\hline 13 & $\begin{array}{c}\text { Labanah Whey } \\
\text { wastewaters }\end{array}$ & $\begin{array}{l}\text { Cylindrical } \\
\text { mem- } \\
\text { brane-less } \\
\text { MFC }\end{array}$ & Graphite & Graphite & $\begin{array}{l}\text { Mixed microbial } \\
\text { consortia }\end{array}$ & $\begin{array}{c}23.23(\mathrm{~W} \\
\left.\mathrm{m}^{-3}\right)\end{array}$ & NA & 72.76 & NA & [144] \\
\hline 14 & $\begin{array}{l}\text { Yogurt waste- } \\
\text { water }\end{array}$ & SC-MFC & $\begin{array}{c}\text { Stainless } \\
\text { steel fiber } \\
\text { felt }\end{array}$ & $\begin{array}{l}\text { activat- } \\
\text { ed C }\end{array}$ & - & 1043 & NA & 88 & 23 & [84] \\
\hline 15 & $\begin{array}{l}\text { Orange peel } \\
\text { waste }\end{array}$ & DC-MFC & $\begin{array}{l}\text { Graphite } \\
\text { felt }\end{array}$ & $\begin{array}{c}\mathrm{Pt}+ \\
\text { graphite } \\
\text { cloth }\end{array}$ & $\begin{array}{l}\text { Anaerobic con- } \\
\text { sortia }\end{array}$ & 358.8 & 590 & 80 & 15.5 & [90] \\
\hline 16 & $\begin{array}{l}\text { Lemon peel } \\
\text { waste }\end{array}$ & DC-MFC & $C$ felt & C cloth & AS & 371 & 580 & 75.8 & $32.30 \%$ & [91] \\
\hline 17 & Citrus waste & SC-MFC & $\begin{array}{l}\text { Plain } \\
\text { graphite } \\
\text { plate }\end{array}$ & $\begin{array}{l}\text { Plain } \\
\text { graphite } \\
\text { plate }\end{array}$ & $\begin{array}{c}\text { anaerobic } \\
\text { bioelectrogenic } \\
\text { consortia }\end{array}$ & 71.1 & 262 & 63.8 & 33.2 & [145] \\
\hline \multirow[t]{2}{*}{18} & \multirow[t]{2}{*}{$\begin{array}{c}\text { Brewery } \\
\text { wastewater }\end{array}$} & \multirow{2}{*}{$\begin{array}{c}\text { DC-MFC With } \\
\text { chitosan/bio- } \\
\text { degradable } \\
\text { copolymer } \\
\text { membrane }\end{array}$} & $\mathrm{C}$ & $\mathrm{C}$ & & \multirow[t]{2}{*}{3882} & \multirow[t]{2}{*}{ NA } & \multirow[t]{2}{*}{70} & \multirow[t]{2}{*}{ NA } & \multirow[t]{2}{*}{ [146] } \\
\hline & & & brush & brush & - & & & & & \\
\hline \multirow{2}{*}{19} & \multirow{2}{*}{$\begin{array}{c}\text { Brewery } \\
\text { wastewater }\end{array}$} & \multirow{2}{*}{ DC-MFC } & \multirow{2}{*}{ C brush } & $\mathrm{C}$ & \multirow{2}{*}{-} & \multirow{2}{*}{4245} & \multirow{2}{*}{ NA } & \multirow{2}{*}{72} & \multirow{2}{*}{ NA } & \multirow{2}{*}{ [146] } \\
\hline & & & & brush & & & & & & \\
\hline 20 & $\begin{array}{l}\text { Winery waste- } \\
\text { water }\end{array}$ & DC-MFC & C-felt & C-felt & activated sludge & 420 & 72 & $\begin{array}{c}650\left(\mathrm{mg} \mathrm{l}^{-1}\right. \\
\left.\mathrm{d}^{-1}\right)\end{array}$ & NA & [147] \\
\hline 21 & $\begin{array}{l}\text { Winery waste- } \\
\text { water }\end{array}$ & DC-MFC & C felts & C felts & activated sludge & 890 & 178 & $\begin{array}{c}600(\mathrm{mg} \\
\left.\mathrm{l}^{-1} \mathrm{~d}^{-1}\right)\end{array}$ & 42.2 & [148] \\
\hline 22 & $\begin{array}{l}\text { Vegetable oil } \\
\text { wastewater }\end{array}$ & $\begin{array}{c}\text { DC-MFC } \\
\text { Operation at } \\
35^{\circ} \mathrm{C}\end{array}$ & $\begin{array}{l}\text { Titanium } \\
\text { rod }\end{array}$ & C cloth & AS & 6119 & 5839 & 90 & 36.5 & [106] \\
\hline 23 & $\begin{array}{c}\text { Soybean edible } \\
\text { oil refinery } \\
\text { wastewater }\end{array}$ & SC-MFC & $\begin{array}{c}\text { Graphite } \\
\text { brush +tita- } \\
\text { nium }\end{array}$ & $\begin{array}{l}\text { Stainless } \\
\text { steel } \\
\text { mesh + } \\
\text { activat- } \\
\text { ed C }\end{array}$ & Activated sludge & 746 & 490 & $93.60 \%$ & 22 & [105] \\
\hline 24 & PMW & $\begin{array}{l}\text { SC-MFC } \\
\text { (with } \\
\text { activated C } \\
\text { addition) }\end{array}$ & C cloth & C cloth & $\begin{array}{l}\text { Anaerobic mi- } \\
\text { crobial sludge }\end{array}$ & 344.3 & 267.1 & 91.9 & 3.06 & [149] \\
\hline 25 & $\begin{array}{c}\text { Starch } \\
\text { processing } \\
\text { wastewater }\end{array}$ & SC-MFC & C paper & $\begin{array}{l}\text { C paper } \\
+\mathrm{Pt}\end{array}$ & - & 239.4 & 490.8 & 98 & 8 & [150] \\
\hline 26 & Soluble starch & SC-MFC & $\begin{array}{l}\text { graphite } \\
\text { fiber felt }\end{array}$ & $\begin{array}{l}\text { graphite } \\
\text { fiber felt }\end{array}$ & AS & 277.6 & 396 & 79.4 & 67.7 & [27] \\
\hline 27 & $\begin{array}{c}\text { Sugarcane } \\
\text { molasses }\end{array}$ & $\begin{array}{l}\text { DC-MFC (H } \\
\text { type) }\end{array}$ & NA & NA & $\begin{array}{l}\text { Brevibacillus } \\
\text { borstelensis }\end{array}$ & 188.5 & 990 & 81.7 & 59.8 & [151] \\
\hline 28 & $\begin{array}{c}\text { Molasses } \\
\text { wastewater }\end{array}$ & $\begin{array}{c}\text { Water- } \\
\text { fall-type MFC } \\
\text { + polyvinyl } \\
\text { alcohol-hy- } \\
\text { drogel as } \\
\text { membrane }\end{array}$ & C felt & C cloth & Activated sludge & 16.1 & 2130 & 90.1 & NA & [152] \\
\hline
\end{tabular}




\section{Acidogeneic food waste leachate}

Food leachate contains a large amount of organic compounds, ammonium nitrogen, heavy metals, organic and inorganic chlorine, salts, etc. Leachate is essentially buried through landfill in some countries such as India [72]. The composition and concentration of leachate contamination is mainly under the influence of the landfill's age [73]. Biological treatment may be one of the most ideal methods due to the high bioavailability of leachate, but the presence of ammonia, sulfides and heavy metals will hamper and reduce the efficiency of the biological treatment process significantly [74]. The food leachate alone can generate electricity, but the addition of the inoculum causes a significant reduction (about 7 days) at the start time. A higher efficiency was achieved when AS was used in MFC with food leachate; the analysis of the anode biofilm microbial community indicated which was due to the richness of two fermentative (Clostridium and Bacteroides) and electrogenics (Magnetospirillum and Geobacter) [75]. For strength wastewater like this, the substrate concentration of above $20000 \mathrm{mg} \mathrm{l}^{-1}$ can inhibit microbial activity in the anode chamber. In addition, the membrane fouling by microorganisms and cations can significantly affect the ion exchange capacity and MFC performance. Recirculation is a great technique used to increase the output power of anaerobic reactors. Especially recirculation indicated when food leachate was used in MFCs and it was effective to enhance the bioelectricity generation [76]. Acidogenic fermentation can be used as a pre-treatment in this kind of wastewater and at the end of the $58^{\text {th }}$ day of fermentation, the COD and $\mathrm{pH}$ of this leachate reached $135.11 \mathrm{~g} \mathrm{l}^{-1}$ and 3.93 respectively [77].

\section{Dairy industry wastewater}

The dairy industry wastewater with complex compounds consists of degradable organic compounds where $97 \%$ of COD contains sugar content [78]. There is a high concentration of fermentable substrates [79]. The compounds in treated MFC effluent may have toxic effects at different ecological levels, which indicates the importance of complete MFC process. As such, toxicity testing in MFC treatment can be useful. In this regard, investigation of acute toxicity indicates the raw dairy wastewater has highly toxic effects, while the MFC effluent is without toxicity effects after complete process [80]. To demonstrate the feasibility of dairy processing wastewater treatment by recovering bioenergy through MFC using dairy wastewater, measuring the amount of extractable energy and highlighting the main sources of energy loss in the system. On average, the MFC especially extracts an energy from $8.95 * 10^{-2} \mathrm{~kW} \mathrm{~h} \mathrm{~kg}^{-1}$ COD with a highest output of $20.53 * 10^{-2} \mathrm{~kW} \mathrm{~h} \mathrm{~kg}^{-1} \mathrm{COD}$ [81]. $\mathrm{n}$ dairy industry, the clear issue is that the MFC is a valuable alternative to effluent treatment and energy generation, while it needs several experiments on largescale in dairy industry [81]. Using modified anode by nanoparticles can reduce cost investment and increase the performance. In this regard, copper-doped iron oxide nanoparticles are a good choice and characterized for wettability and electrochemical analysis. The coated anode indicated a good hydrophilic property in wettability. It increased potential, decreased resistance where Pdm of $161.5 \mathrm{~mW} \mathrm{~m}^{-2}$ and COD removal of $74 \%$ were obtained [82]. The yogurt wastewater was found able to start an MFC using its natural microflora [83]. Alkaline conditions (pH 10.5) are useful for treating the yogurt wastewater. However, solids suspension can be removed using a pretreatment precipitate at first. Due to increase of the COD concentration from optimum during treatment in MFC with yogurt wastewater, the IR increase and the viability of bacteria is reduced in the anode biofilm. Thus, the electricity generation diminishes [84].

\section{Whey}

It is a by-product of the cheese production with a high content of organic compounds, mainly a mixture of lactose and protein. The whey contains $4-5 \%$ carbohydrate, up to $1 \%$ protein, $0.5-0.4 \%$ fat, less than $1 \%$ lactic acid, and $1-3 \%$ salt [85]. The primary density of microorganisms has a great role in MFC performance where the pre-incubate anode can improve performance in this treatment. Hence, anodes were enriched with microorganisms inherent to whey from 1 to 3 months before MFC activity. The result significantly enhanced and offered CE of $80.9 \%$, COD removal of $92.8 \%$, and Pdm of $1800 \mathrm{~mW} \mathrm{~m}^{-2}$ [86]. Two biological methods, MFC to traditional technology (fermentation by Lactobacillus bulgaricus) have been compared for treating whey and condensed whey. The results prove that the biological wastewater treatment is a very suitable and efficient alternative for traditional wastewater treatment. In the traditional method, during the continuous process for both whey and condensed whey, the removal of COD was over $70 \%$ while with MFC was $95 \%$ and $78 \%$. Further, in the MFC method, the Pd values of $188.8 \mathrm{~mW} \mathrm{~m}^{-2}$ and $288.12 \mathrm{~mW} \mathrm{~m}^{-2}$ with the CE of $26 \%$ and $15 \%$ were obtained for whey and condensed whey respectively. Obviously due to the higher content of organic compounds, the power produced of condensed whey is about twice the whey itself [87].

The filter-sterilized (effluent mainly containing lactose) and acidified (effluent mainly containing acids) (after $48 \mathrm{~h}$ of fermentation at mesophilic temperature) cheese whey are suitable pre-treatments. The initial COD concertation and initial $\mathrm{pH}$ are important parameters to reach optimum acidification and energy recovery in the form of hydrogen. In MFC, a Pdm of $1.57 \mathrm{~W} \mathrm{~m}^{-3}$ was obtained through acidification and $3.26 \mathrm{~W} \mathrm{~m} \mathrm{~m}^{-3}$ through filtering [88]. Also, dark fermentation can be used as a pre-treatment where the hydrogen and an effluent rich in volatile fatty acids are produced, which are used in MFC. In this regard, a Pd of $0.34 \mathrm{~mW} \mathrm{~m}^{-2}$, CE of $14 \%$, and COD elimination of $41 \%$ were obtained with raw whey. On the other hand, a Pdm of $439 \mathrm{~mW} \mathrm{~m}^{-2}$ was achieved by dark fermentation effluent, which is 1000 times larger compared to raw whey, with CE of $24 \%$ and COD removal of $100 \%$ obtained. The main electrochemical performance difference of both MFCs was analyzed. In this regard, Geobacter, Pseudomonas and Thauera were the dominant electroactive population when fed by dark fermentation effluent, while the 
clostridium and lactobacillus were the dominant electroactive population when directly fed with raw whey. Also, in MFCs fed with raw whey, the low variety may increase the growth of lactic acid bacteria and cause acidification of the environment by fermentation of lactose. These microorganisms are known to produce bacteriocin; thus, they can succeed in a competition with exoelectrogenics. In addition, the $\mathrm{pH}$ in dark fermentation effluent was constant as the volatile fatty acids contained were absorbed completely [89].

\section{Juice industry wastewater}

The juice industry wastewater is characterized by biodegradability due to sugar as its main contamination (glucose and fructose) [25]. About 50-60\% of the weight of the processed fruit is converted into peel waste which includes peel, seeds, and residue of internal coatings [90]. The changes in the concentration of inflow organic compounds may influence the function and composition of the microbial community [83]. The key components of orange peel waste, called pectin and cellulose, were also tested in a pure form. There was a stable current by pectin, while using cellulose alone as substrate did not produce a significant current. Thus, the absence of bacteria, which can degrade cellulose, was clarified and the activity of the enzymes of pectinase and polygalacturonase was detected [90]. Ultra-sonication can also be used as pre-treatment to enhance the power generation due to the increase of soluble COD and the degradation kinetics of the lemon peel substrate [91]. The photosynthetic biocathode could increase system performance with juice industry wastewater. This biocathode provided oxygen in the role of electron acceptor and contained a pure culture of Chlorella Vulgaris. By performing a few experiments, it was determined that the output power was obtained more rapidly and more stably in the continuous flow mode $\left(23.97 \mathrm{~mW} \mathrm{~m}^{-2}\right.$ ) (with microorganisms in biofilm and in suspension) than in batch mode ( $\mathrm{Pdm}$ of $22.85 \mathrm{~mW} \mathrm{~m}^{-2}$ ). It was also evident that up to $1066 \mathrm{mg} \mathrm{COD}^{-1}$ could be treated successfully in this system. However, the cell voltage dropped from 15 to $10 \mathrm{mV}$ when the COD level increased from 343 to $1066 \mathrm{mg} \mathrm{COD} \mathrm{l}^{-1}$ [92]. An MFC does did start the fermented apple juice using its natural microflora. In this regard, compost leachate as an inoculum was used where Pdm $78 \mathrm{~mW} \mathrm{~m}^{-2}$ was obtained. Also, the AS was used with the Pdm $43.7 \mathrm{mWm}^{-2}$ obtained [83]. The OCV of $0.4 \mathrm{~V}$ and Pdm of $31.58 \mathrm{~mW} \mathrm{~m}^{2}$ were obtained using cashew apple waste in MFC [93].

\section{Brewery industry wastewater}

The brewery wastewater contains many organic compounds in the water, including sugary, starch and protein compounds produced at various stages, such as saccharification, fermentation, cooling, washing, etc. Generally, the COD of these wastewaters is $3000-5000 \mathrm{mg} \mathrm{l}^{-1}$ [94]. Adding mediators such as phosphate buffer can increase the output power by $185 \%$ [95]. In a tubular air-cathode MFC, the treatment efficiency was $93 \%$ which is a very good performance, but compared to other reports the output power was $96 \mathrm{~mW} \mathrm{~m}^{-2}$ which was poor [96]. However, researchers have designed an MFC pilot-scale combining 40 tubular MFCs with a 10-liter capacity per day, which also showed a treatment efficiency of $86.4 \%$, but the output power did not increase at all and it remained the same [97]. A 20-L continuous flow MFC (containing two 10L MFCs) with low investment cost was designed which worked for over one year with significant and stable performance, where COD removal of 94.6 with Pdm of $18.70 \mathrm{~mW} \mathrm{~m}^{-2}$ (in 228 day) were obtained [98]. Membrane fouling is considered as a challenge in MFCs especially for this kind of wastewater. The anaerobic baffled reactor including sediment MFC was integrated with anaerobic/aerobic membrane bioreactor (MBR). Every 24h, the back flush with water and aeration with air in anaerobic MBR were able to inhibit the fouling growth. Meanwhile, regular aeration was more effective than back flush, though it could be more effective if both ways were performed at the same time. The aerobic MBR indicated a higher stable effluent quality and higher performance in treatment. In this regard, only $0.52 \% \sim 0.99 \%$ of output power was used for fouling mitigation in anaerobic MBR, but $31.80 \%$ of power was required in aerobic MBR, showing a very significant difference [99].

\section{Winery industry wastewater}

There is acidic $\mathrm{pH}$, high organic content with low $\mathrm{N}$ and $\mathrm{P}$ concentrations, significant polyphenols, macro and micronutrients and heavy metals in all kinds of winery wastewater. The winery wastewater is produced during crushing, pressing, and washing the fermentation tanks, barrels, machines, and production rooms. The characteristics of wastewater winery are described as undesirable proportion of COD / N and COD / $\mathrm{P}$ [100]. Even when $\mathrm{P}$ and $\mathrm{N}$ were added, the COD removal was not effective. Daily removal fluctuated around $1000 \mathrm{mg} \mathrm{l}^{-1} \mathrm{~d}^{-1}$ and during a complete test period COD removal was $17 \%$. However, the electricity generation was affected positively by increasing the concentration of $\mathrm{P}$ and $\mathrm{N}$. Thus, CE increased from about $2 \%$ to $15 \%$ and Pdm rose from $105 \mathrm{~mW} \mathrm{~m}^{-2}$ to $465 \mathrm{~mW} \mathrm{~m}^{-2}$ by adding $\mathrm{P}$ and $\mathrm{N}$ [100]. When comparing white and red wine, degradation of existing organic compounds is critical, hence BOD / COD of white wine settling was 0.93 while for red wine settling it was 0.33 . Also, polyphenols at high concentrations can inhibit the process in red wine settling. Particularly in the anode, different types of substrates lead to formation of the different bacterial consortium. It was found that the COD removal, output power, and CE in white wine are greater than those of red wine [101]. It is clear that in order to achieve the desired performance, modification in the composition of the effluent is required by adding some items. In particular, adjusting the COD / N and COD / P ratios as well as BOD / COD is in demand.

\section{Oil industry wastewater}

The vegetable oil industry wastewater contains high amounts of sulfate and other organic materials. Some changes in the process will lead to better results; in particular, the membrane plays a key role in various processes. In this regard, wastewater from an oil refinery was treated using an MBR including 
ultrafiltration and microfiltration [102-104]. There was a positive correlation between the amount of COD and voltage generation in MFCs. In comparison to some industrial wastewaters and chemical wastewaters with higher COD, a suitable efficiency in voltage generation $(890 \mathrm{mV})$ and more COD removal $(87 \%)$ were obtained using vegetable oil wastewater (Ghee Industries). In addition, phosphate removal of $47 \%$ and sulfate removal of $42 \%$ were obtained [57]. In addition, the concentration of volatile fatty acids increased in the effluent by elevating the organic loading of COD, which were mainly acetate and propionate. The propionate showed the highest concentrations at the highest COD concentrations in MFC [105]. Regarding the operation temperature, an increase in MFC efficiency was achieved with an increase in the operation temperature and time. The performance of mesophilic microorganisms rose to a certain level by increasing the temperature from $25^{\circ} \mathrm{C}$ to $35^{\circ} \mathrm{C}$ [106]. For soybean edible oil refinery wastewater, some pre-treatment can be used for removing the harmful and problematic solvent compounds such as gravitational separation, slag scraping, flotation, emulsion breaking, and flocculation [107]. The olive and olive oil wastewater with toxic properties contain free fatty acids, carbohydrates, and phenolic compounds. Phenolic compounds have a determinant role in biological treatment due to their antimicrobial properties. In order to improve the efficiency, a physicochemical pre-treatment before anaerobic digestion has been proposed for reducing the olive oil toxicity. With olive mill wastewater in a SC-MFC, a maximum voltage of $381 \mathrm{mV}$ was obtained. COD elimination of $65 \%$ and phenols elimination of $49 \%$ were achieved using the process. A great decline was also obtained in the 3,4-dihydroxybenzoic acid, tyrosol, gallic acid, and p-coumaric acid. When treated pure phenols were tested instead of this wastewater, it was proved that 3,4-dihydroxybenzoic acid and caffeic acid do not affect the power generation, while propyl gallate suppresses the voltages production [108].

\section{Palm oil mill wastewater (PMW)}

The complex compounds of PMW with COD of 50,000mg $\mathrm{l}^{-1}$ consists of amino acids, mineral materials, short fibers, organelles, N compounds, organic acids and carbohydrates, such as hemicelluloses as well as simple carbohydrates [109]. PMW is a high strength effluent. In this regard, an effluent with a 1:50 dilution (964 $\mathrm{mg} \mathrm{COD} \mathrm{l}^{-1}$ ) was compared to effluent without dilution. The Pd decreased to about $22 \mathrm{~mW} \mathrm{~m}^{-2}$, but the removal efficiency of COD and ammonium nitrogen and CE rose to about $70 \%, 75 \%$, and $24 \%$ respectively [110]. On the one hand, it is evident that the higher initial COD sample led to greater electricity generation and less COD removal. On the other hand, the lower initial COD sample indicated more COD removal, but electricity generation was dropped. It reveals an inverse relationship between electricity generation and COD removal. In comparison to anaerobic microflora, controlled inoculum can increase the output power but with a weaker result in COD removal. This difference is due to the absence of a wider range of the microorganisms such as fermentative microorganisms in controlled inoculum which are able to use more organic compounds. In this regard in a DC-MFC, the controlled inoculum (isolated from AS) was compared with AS inoculum. A Pdm of $107.35 \mathrm{~mW} \mathrm{~m}^{-2}$ was obtained with controlled inoculum which was about three times greater than that of the usual AS inoculum $\left(33.62 \mathrm{~mW} \mathrm{~m}^{-2}\right)$. Also, CE of $74 \%$ was obtained with controlled inoculum which was $50 \%$ higher than that of the usual AS (24\%). The COD removal efficiency for controlled inoculum was less than $32 \%$, which was lower than the usual AS [111]. Further, the PMW natural anaerobic microflora and pure isolated culture of PMW, where Pseudomonas aeruginosa ZH1 was identified, as an inoculum were used in a DC-MFC. Using Pseudomonas aeruginosa ZH1, a Pdm of $451.26 \mathrm{~mW} \mathrm{~m}^{-2}$ was reported, 5 times greater than MFC with AS PMW $\left(85.11 \mathrm{~mW} \mathrm{~m}^{-2}\right)$. The maximum COD elimination of $13 \%$ was obtained from AS PMW and 3\% was obtained with Pseudomonas aeruginosa ZH1 [112]. Some integration methods can be used for PMW treatment. The MFC integration into anaerobic MBR can be effective on filtration efficiency. The MFC has a pre-treatment role before the anaerobic MBR. The anaerobic MBR can further treat the effluent from MFC. In the integrated system with direct feeding, the filtration efficiency indicated a significant development. In addition, decrease in polysaccharide concentration was observed which in turn suggested a better filtration performance [113]. Immobilized biological aerated filters have a great effect on the removal of COD and $\mathrm{NH}_{3}-\mathrm{N}$. A two-phase cylinder MFC and immobilized biological aerated filters were used. The COD removal of $96.5 \%$ and $\mathrm{NH}_{3}-\mathrm{N}$ removal of $93.6 \%$ were obtained and the Pdm was obtained $44.6 \mathrm{mWm}^{-2}$ [114]. Ultrasound can reduce the delay time in bioelectricity generation and improve the performance. It increased by $25 \%$ and reached $18.3 \mathrm{~W} \mathrm{~m}^{-3}$. In addition, COD removal increased from $30 \%$ to $54 \%$ [115].

\section{Starch industrial wastewater}

The starch industry produces extensive high-strength wastewater within a COD range of 16870 to $22800 \mathrm{mg} \mathrm{l}^{-1}$ with wide levels of carbohydrates, cellulose, protein, and other nutrients [116]. Biological conversion of starch processing wastewater is beneficial for recovery of resources such as the microbial biomass protein and biopesticide [12]. Electrogenesis species such as Shewanella oneidensis alone are unable to initiate the process and generate electricity using starch. The electricity can be produced by two-stage fermentation of starch. Streptococcus bovis 148 can produce lactic acid by metabolizing starch where Shewanella oneidensis MR-1 can generate power using lactic acid. In separate fermentation (first by Streptococcus bovis 148 followed by Shewanella oneidensis MR-1), a Pdm of $49.9 \mathrm{~mW} \mathrm{~m}^{-2}$, and CE of $10.2 \%$ were obtained. In parallel fermentation (using both bacteria at the same time), a Pdm of $12.1 \mathrm{~mW} \mathrm{~m}^{-2}$ and CE of $4.7 \%$ were obtained [117]. The results indicated that two-stage fermentation has a higher performance in comparison with parallel fermentation in one stage. 


\section{Molasses wastewater (beet and sugarcane)}

The molasses from sugarcane and sugar beet are inexpensive and available. Hence, it is used in the fermentation industry such as molasses-based distillery industry as a raw material. The molasses process and sugar beet process can produce a wastewater with high COD (65000-130000 $\mathrm{mg} \mathrm{l}^{-1}$ ) [118] and it seems to have suitable properties for use in MFC as substrate. Low substrate conversion rates are a major constraint on MFC performance using molasses wastewaters [119]. As a result, integration with other systems is a great way to overcome this problem. An anaerobic baffled stacking MFC with a combination of four units can improve the output power. The Pd average of $115.5 \mathrm{~mW} \mathrm{~m}^{-2}$ was obtained for four units, where a total COD removal efficiency of $50-70 \%$ was obtained [118]. An integrating system including three parts of an up-flow AS blanket reactor-MFC-biological aerated filter could enhance the treatment efficiency of beet sugar molasses. In this system, COD and sulfate majorly were reduced by up-flow AS blanket reactor; the MFC was responsible for the oxidation of produced sulfide and power production, where the dye and phenol derivatives were removed by biological aerated filter, where a Pdm of $1410.2 \mathrm{~mW} \mathrm{~m}^{-2}$ was obtained. The initial COD was $127500 \mathrm{mg} \mathrm{l}^{-1}$ and removal efficiencies of COD, sulfate and color were $53.2 \%, 52.7 \%$ and $41.1 \%$ respectively [120]. Totally, it can be stated that PEM can reduce the recovery of electrons in the form of electricity more than expected, where electrons may be lost due to release of oxygen (totally 28\%) [37] Integration of the dark fermented sugar cane molasses with MFC can improve the energy recovery. After fermentation, the remaining energy in the substrate can be extracted by MFC. The total carbohydrates and COD reduction in MFC were about $88 \%$ and $85 \%$ respectively, along with a Pd of $3.02 \mathrm{~W} \mathrm{~m}^{-3}$. A slightly alkaline anodic $\mathrm{pH}$ was more effective in the MFC and could improve its performance. Thus, using an alkaline pre-treatment, the process was carried out at $\mathrm{pH}$ 7.5 [119]. In this regard, the system performance was enhanced to maximum when $\mathrm{pH}$ increased from 6 to 8 , which may be related to the efficient extracellular electron transfer at $\mathrm{pH}$. The distillery wastewater from sugarcane molasses was used where the Pdm and COD removal were obtained $63.8 \mathrm{~mW} \mathrm{~m}^{-2}$ and $63.5 \%$ at $\mathrm{pH}$ 8 , respectively [121]. Another study examined the effect of fed $\mathrm{pH}$ (5.4-10) and buffer situations on power generation and treatment performance in DC-MFC with distillery wastewater from sugar beet molasses. A Pdm of $168 \mathrm{~mW} \mathrm{~m}^{-2}$, COD elimination of $68.2 \%$, color elimination of $26.4 \%$, and TDS elimination of $15.4 \%$ were obtained at $\mathrm{pH}$ 8. The $\mathrm{Pdm}$ of $194.7 \mathrm{~mW} \mathrm{~m}^{-2}$ was obtained when borate buffer was used in the anode. The results revealed that the activity of exolectrogenic microorganisms was significantly influenced by $\mathrm{pH}$ and also led to increased conductivity; as such, the alkaline conditions of $\mathrm{pH} 8$ and borate buffer produced the best efficiencies of treatment and power generation [122]. It is clear that slightly alkaline conditions could improve the system performance.

To compare SC-MFC and DC-MFC in molasses wastewater treatment, their performance in treatment and output power should be considered. Two types of SC-MFCs with/without the PEMs and a DC-MFC were investigated. In both SC-MFCs, the values of COD removal and output power were similar. This indicates that the PEM does not increase the performance. The COD removal was achieved $90 \%$ and $50 \%$ for SC-MFC and DC-MFC respectively. However, a Pd of $17 \mathrm{~mW} \mathrm{~m}^{-2}$ was obtained in DC-MFC which is 2.2 times higher than in SC-MFCs. The Proteobacteria value in DC-MFC was 2 to 3 times higher than SC-MFC which is a determinant factor in power generation [123].

\section{Chocolate industry wastewater}

The chocolate industry wastewater is known as a non-toxic effluent with high total solid content and high COD. In DC-MFC, membrane or salt bridge can be used for connecting two chambers, which are effective on performance, where chocolate industry wastewater was used with activated sludge. Via membranes, a Pdm of $1.5 \mathrm{~W} \mathrm{~m} \mathrm{~m}^{-2}$ was obtained, while vie salt bridge Pdm of $0.94 \mathrm{~W} \mathrm{~m}^{-2}$ was obtained with $100 \Omega$ external resistance, and finally MFC with


of $65 \%$ was observed in COD. The total solids content decreased by $68 \%$ and soluble solids by $50 \%$. In addition, chocolate industry wastewater was used in cathode, as catholyte and it had a good result with a Pd of $1.02 \mathrm{~W} \mathrm{~m}^{-2}$ as compared to an air-cathode with

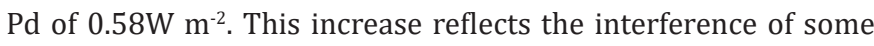
of the additional factors of wastewater (chemical and microbial). Meanwhile, the results were improved using the ferricyanide, but the ferricyanide is a known catholyte suffering limitations such as high costs and the continuous replacement need in MFC. With adequate electricity generation through wastewater in the cathode, the cathode can be considered as an appropriate biotic cathode in which bacteria make the process more stable and cheaper where there is no need for an additional catalyst [124]. Some operational parameters can change to increase the system performance. In this regard, an annular SC-MFC with the chocolate wastewater treatment was used. Optimizing the distance between the electrodes and $46.15 \%$ distance reduction from $1.3 \mathrm{~cm}$ to $0.7 \mathrm{~cm}$ which resulted in a decrease in IR from 100 to $50 \Omega$. Thus, the Pd increased from 7.98 to $22.898 \mathrm{~W} \mathrm{~m}^{-3}$ and the COD removal of $90 \%$ was obtained [125]. The same group in the following, continued to optimize the system. The system's performance was increased about $88 \%$ by elevating the temperature from $25^{\circ} \mathrm{C}$ to $35^{\circ} \mathrm{C}$. The $\mathrm{Pd}$ of $16.75 \mathrm{~W} \mathrm{~m}^{-3}$ was the highest in the $\mathrm{pH} 7$ with $\mathrm{CE}$ of $45.1 \%$, which is the preferred $\mathrm{pH}$ for maximum microbial activity. In the effluent, a significant reduction in COD of $91 \%$ and turbidity of $78 \%$ were obtained [126].

\section{Cereal industry wastewater}

The wastewater of the protein-based food industry can be regarded as non-toxic due to low dangerous compounds with high BOD as well as high organic compounds content. It may also consist of simple sugars and starches [127]. The cereal industries wastewater can be considered by hydrogen production and MFC technologies. With fermentation of sugars, hydrogen is produced, but many organic compounds remain in the effluent and they 
can be used by MFC. It is evident that integrating an MFC to the hydrogen production system (with high-sugar effluent where the major bio-hydrogen by-product is propionic acid) can increase the MFC performance. A Pdm of $371 \mathrm{~mW} \mathrm{~m}^{-2}$ was obtained by SCMFC and cereal industry wastewater [128].

\section{Tomato industry wastewater}

The peel and grain in the tomato pomace contain a high nutritional value and have great potential for energy extraction by MFC. The seeds have a high thermal value and are composed of protein, lipids and carotenoids. The peel is rich in amino acids and carotenoids. Thus, they are rich in $\mathrm{C}$ and N. One gram of cull tomato contains half a microgram of riboflavin and thiamine, both of which can be used as an electron transfer mediator to improve exoelectrogen extracellular respiration in MFCs. As a result, redox mediators in MFC are endemic pomace. The tomato pomace has been used recently in MFC with Pdm of $132 \mathrm{~mW} \mathrm{~m}^{-2}$ obtained. The low efficiency of tomato pomace MFC compared to glucose (Pd of $169 \mathrm{~mW} \mathrm{~m}^{-2}$ ) can be due to the slow kinetics of hydrolyzing, such as limited availability of COD in the electrolyte and its particle characteristics [129].

\section{Seafood processing wastewater}

The wastewater of seafood processing industry consists the high organic content which includes blood, fish head, intestinal and meat remains [130]. A tubular up-flow MFC can be used for treatment of seafood processing wastewater. A Pdm of $105 \mathrm{~mW}$ $\mathrm{m}^{-2}$ and CE of $28.03 \%$ were obtained, where the total and soluble COD removal were obtained $83 \%$ and $95 \%$, respectively. Also, the Pdm was obtained $222 \mathrm{~mW} \mathrm{~m}^{-2}$ when the phosphate buffer was used as a catholyte [131]. Salty seafood wastewater can be treated by MFC, higher than 3 to $5 \%$ of salt distinguishing it from other industrial wastewaters. A Pdm of $16.2 \mathrm{~W} \mathrm{~m}^{-3}$ with CE of $15 \%$ were obtained at 4.2-hour HRT, while up to $80 \%$ removal of the COD content and biological nitrification were obtained. It is evident that HRT is effective on the Pd and a high HRT can improve the ability of removing the soluble COD as well as biological nitrification. High salinity and the other factor in wastewater can activate a low and constant IR about 100 in all experiments. Sub-Components of Wastewaters
In addition, the wastewater $\mathrm{pH}$ was close to the normal level in both chambers [132]. To solve the blockage problem of seafood wastewater, an MFC with up-flow bio-filter circuit was developed as non-chemical without additives. A Pdm of $9.47 \mathrm{~mW} \mathrm{~m}^{-3}$ and maximum COD removal efficiency $94.37 \%$ were obtained with $\mathrm{pH}$ 5.6-6.5 and aeration of $2.0 \mathrm{lmin}^{-1}$ [133]. This configuration was able to overcome the blockage problem effectively.

\section{Mustard tuber wastewater}

Fuling mustard tuber is a popular pickle around the world. It produces high strength wastewater and salinity in large volumes during the production process. This effluent was used in a DC-MFC with the entire experiment divided into 4 sections characterized by concentration elevation of primary clarifier effluent. A Pdm of $246 \mathrm{~mW} \mathrm{~m}^{-2}$, CE of $67 \%$, and COD removal of $57 \%$ were obtained for the first sections. COD removal of $85 \%$ was achieved from the fourth sections as the highest COD removal; however, the power recovery efficiency was very low [134]. It can be concluded clearly that there is a significant negative correlation between the concentration of the primary clarifier effluent and the maximum cell voltage, and there is a significant positive correlation between the concentration of primary clarifier effluent and the IR. Accordingly, the colloidal complexes and particles in the primary clarifier effluent increased the IR gradually and subsequently reduced the power output. Further, this effluent can be used as a catholyte when a combination of different biocathodes is used. There was simultaneous removal of chemicals and $\mathrm{N}$ in cathodes, where most of the contamination was reduced during the acclimating period. Given the removal of N, aerobic and anaerobic microenvironments can form inside the cathodic biofilm and perform both heterotrophic denitrification and BE denitrification. A Pdm of $1.32 \mathrm{~W} \mathrm{~m}^{-3}$ was obtained where the COD and ammonium both reduced by $99 \%$ [135]. The MFC had similar performance in the same steps, which may suggest that this wastewater is an adequately self-buffered catholyte. The oxygen in a cathode leads to low bacterial activity by the over-potential and it can create essential constraints for energy recovery which should be reduced.

Table 6: MFCs Performance with Sub- Components of Wastewater.

\begin{tabular}{|c|c|c|c|c|c|c|c|c|c|c|c|}
\hline NO & Substrate & $\begin{array}{l}\text { MFC } \\
\text { Type }\end{array}$ & Anode & $\begin{array}{l}\text { Cath- } \\
\text { ode }\end{array}$ & Inoculum & Pd (mW m-2) & $\begin{array}{l}\text { Voltage } \\
\text { (mV) }\end{array}$ & $\begin{array}{c}\text { Substrate } \\
\text { Removal \% }\end{array}$ & CE\% & Special Note & Ref \\
\hline 1 & 2,4-DCP & $\begin{array}{l}\text { DC- } \\
\text { MFC }\end{array}$ & C cloth & C cloth & $\begin{array}{l}\text { Bacillus } \\
\text { Subtilis }\end{array}$ & 9.5 & 450 & 60 & 23 & $\begin{array}{l}\text { Potassium } \\
\text { Persulfate as } \\
\text { catholyte }\end{array}$ & [159] \\
\hline 2 & $\begin{array}{l}\text { Nitro- } \\
\text { benzene } \\
\text { wastewa- } \\
\text { ter }\end{array}$ & $\begin{array}{l}\text { CW- } \\
\text { MFC }\end{array}$ & $\begin{array}{l}\text { Graph- } \\
\text { ite felt }\end{array}$ & $\begin{array}{l}\text { Graph- } \\
\text { ite felt }\end{array}$ & AS & 19.5 & 590 & 93.9 & NA & $\begin{array}{l}\text { Scirpus validus } \\
\text { was used }\end{array}$ & [160] \\
\hline
\end{tabular}

In addition to the main components, the food industrial wastewaters may also contain sub-components such as phenol compounds and nitrobenzene. The presence of these compounds in wastewater may have various effects such as inhibition on microbial activity which should be investigated. The results of MFCs performance with some wastewaters with sub-components as substrate are presented in Table 6. 


\section{Phenolic compounds}

There are toxic contaminants such as phenolic compounds in industrial effluents. In many industrial wastewaters, phenolic compounds are major toxic contaminants such as chemical, pharmaceutical, textile, food, and oil refining. Compared to the conventional anaerobic degradation, MFCs efficiency are comparable to the high efficiency of 2,4-Dichlorophenol $(2,4-$ DCP) degradation. Phenol as a substrate was used in air-cathode SC-MFCs. The results showed that using the initial concentration of $600 \mathrm{mg}$ phenol $\mathrm{l}^{-1}$ with glucose inoculation, Pdm was obtained $31.3 \mathrm{~mW} \mathrm{~m}^{-2}$ which was 1.9 times higher than using phenol alone, as a substrate. Also using closed circuit voltage and OCV, the phenol degradation values were $89 \%$ and $77 \%$ respectively with CE obtained $3.68 \%$. Sodium acetate and sodium propionate were other compounds tested for inoculation which were weaker than glucose in all cases. Examining the IR of these cases, the MFC with glucose produced the lowest IR, even compared to MFC with phenol alone; as a result, it is one of the reasons for producing higher Pd. Glucose is a fermentable substrate and during the process in SC-MFCs, it can be broken down into some non-fermentable substrates (such as acetate and ethanol). Glucose may lead to a stimulated growth of the microbial population of the entire anode, which increases the activity of electrochemical biofilms of anode causing different performances [153]. The effluent coconut husk retting contains recalcitrant compounds such as phenol. Thus, it must be treated before being released in the environment. It was used in DC-MFC with batch mode and a Pdm of $362 \mathrm{~mW} \mathrm{~m}^{-2}$ was obtained. The COD removal of $91 \%$ was obtained with CE of $25 \%$. In addition, a high phenol removal of $93 \%$ was achieved using a primary concentration of $320 \mathrm{~g}$ phenol $\mathrm{m}^{-3}$ [154]. For using phenol in the cathode, investigations were carried out using the ammonium and phenol fed to an aerobic cathode in a SC-MFC. The results showed that the phenol had no certain inhibitory effect on the nitrifying even up to a level of $600 \mathrm{mg} \mathrm{l}^{-1}$. Compared to the conventional aerobic bioreactor with the same MFC under open circuit conditions, nitrification and higher rate of $\mathrm{N}$ elimination was less suppressed by phenol in MFC. Bacterial analysis showed that the electrochemical active bacteria and denitrifiers in the anaerobic chamber have an important role in the output power and anaerobic denitrification, while in aerobic cathode the degrading bacteria of phenol are responsible for phenol oxidation, with aerobic nitrification performed by nitrifiers and aerobic denitrification by denitrifiers [155].

\section{Nitrobenzene}

Nitrobenzene is widely used to produce pesticides, paints, explosives, rubber, and other chemical compounds. In the groundwater, the nitrobenzene compounds are highly toxic, bio-accumulative, and are stable in groundwater. In CW, the high concentration of nitrobenzene can inhibit the activity of microorganisms and reduce the nitrobenzene removal efficiency
[156]. SC-MFCs designed with pre-enriched anodes can be useful for nitrobenzene elimination and power generation. A Pdm of over $25 \mathrm{~W} \mathrm{~m}^{-3}$ was obtained when the nitrobenzene concentration

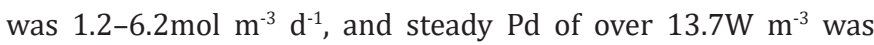
generated within nitrobenzene concentration of $1.2-14.7 \mathrm{~mol} \mathrm{~m}^{-3}$ $d^{-1}$. A nitrobenzene elimination over $97 \%$ was obtained even when the nitrobenzene-loading rate was reached $17.2 \mathrm{~mol} \mathrm{~m}^{-3} \mathrm{~d}^{-1}$. The potential product of nitrobenzene reduction such as aniline can be eliminated efficiently [157]. Xie et al [158] combined a membraneless air-cathode SC-MFC with CW for finding a possible treatment with good nitrobenzene removal efficiency. The wastewater was tested on a typical MFC and CW-MFC. Pdm values of $0.59 \mathrm{~mW} \mathrm{~m}^{-2}$ and $1.53 \mathrm{~mW} \mathrm{~m}^{-2}$ were achieved for MFC and CW-MFC respectively. The CE for MFC and CW-MFC was $13.9 \%$ and $16.4 \%$, respectively. The highest nitrobenzene elimination was obtained $92.89 \%$ at CW-MFC while the nitrobenzene concentration to COD was 1:16 with HRT in 24 hours. The COD removal obtained ranged from $67.92 \%$ to $78.30 \%$ where the CW-MFC was more effective for COD reduction. Also, glucose was applied as a $\mathrm{C}$ source in this wastewater, where co-metabolism due to microorganisms and glucose can simulate the nitrobenzene reduction.

\section{Municipal Wastewater}

The municipal wastewater is a complete wastewater in terms of structure and constituents; it is a collection of fundamental factors and component. This wastewater emanates from any domestic, industrial, commercial or agricultural activities, surface runoff, storm water, and any sewer inflow or wastewater infiltration. Food waste forms a large part of municipal wastewater which is about $27 \%$ [161]. The loss or wasting of food products is a global issue claiming one-third of total wastes [162]. The chemical energy of municipal wastewater is at least about $13 \mathrm{~kJ}$ $\mathrm{g}^{-1} \mathrm{COD}$ and it is approximately 9 times more than the prevalence required to treat this wastewater [163]. To treat the municipal wastewater, approximately $35.2 \mathrm{kWh}$ per population equivalent and year is required in Germany [164]. The effluent of the primary sedimentation reservoir is one of the best choices to use as substrate in MFC or integrate MFC into treatment plants; This effluent is relatively low solid content and it minimizes the risk of clogging or sloughing in MFC [164].

Some large-scale MFCs are investigated for municipal wastewater treatment. The stackable horizontal MFC was designed which consisted of several 250L units. During the sustained operating period, A Cdm of 0.435 A was seen in each module where Pdm of $116 \mathrm{~mW}$ was obtained. The COD removal of $79 \%$ and total $\mathrm{N}$ removal of $71 \%$ were obtained and CE was $5 \%$ [165]. In addition, the energy extraction via an MFC with 200L system (effective volume of 100L) was investigated. There were three rows of MFCs in the connection with the highest output power of $114 \mathrm{~mW}$. The organic compounds removal of $75 \%$ and solids removal of $80 \%$ were obtained [166]. Further, in the largest research ever done in terms of scale, a $1000 \mathrm{~L}$ modularized MFC 
was developed which worked for more than one year (a stack containing 50MFC, with $20 \mathrm{~L}$ volume for each one). The removal rate of $70-90 \%$ was obtained. A Pdm of $125 \mathrm{~W} \mathrm{~m}^{-3}$ was generated with synthetic wastewater, while it ranged from 7 to $60 \mathrm{~W} \mathrm{~m}^{-3}$ municipal wastewater. The CE was obtained within the range of $41-75 \%$. Using HRT of $2 \mathrm{hr}$, energy recovery was obtained $0.033 \mathrm{kWh} \mathrm{m}^{-3}$ from municipal wastewater [167]. A 45L pilot MFC includes four membrane-less SC-MFCs combined into a full-scale municipal wastewater treatment plant for 9 months, perhaps it is one of the best ways for integration. The best results were obtained by removing $24 \%, 40 \%$, and $28 \%$ for COD, TSS, and $\mathrm{N}$ respectively in HRT of $22 \mathrm{hr}$. The average Pd was more than one cycle for quaternary cells in the same HRT where Pd of $82 \mathrm{~mW}$ $\mathrm{m}^{-2}$ was obtained. The mean normalized energy recovery was obtained $0.36 \mathrm{kWh} \mathrm{kg}^{-1}$ COD degraded and CE was 24.8\% [164]. The results indicated that an MFC with balanced function among the individual units would be very important for energy extraction. As such, the poor performance of an MFC had a negative effect on the entire efficiency of the connected MFCs [166].

\section{Domestic wastewater}

Domestic wastewater is kind of wastewater derived from plumbing fixtures and appliances such as toilets (urine, stool and toilet paper), bathrooms, laundry, dishwashers, garbage disposal and cleaning which forms part of municipal wastewater. Given the nature of this wastewater, it seems to be a suitable option for use in MFC. So far, clear and suitable results have been obtained due to the use of this wastewater in MFC. It has even been shown in some cases where the electricity generated by MFC with this wastewater can be used in a practical way in the homes. Now researchers are seeking better results with novelty in configurations, designs, operational parameters and large scales. In this regard, a stack of MFC including 40 individual air-cathode units was examined with a continuous flow. It is evident that the removal of pollutants, electricity production, and microbial communities changed significantly when the MFC stack was changed from unrelated to series or parallel connections. When the units were unconnected, Bacillus and Lysinibacillus were the main bacterial species in the anode. Then, after changing from unconnected to series and parallel connections, Pseudomonas aeruginosa followed by different Bacilli classes formed the dominant species in the stacked MFC. The voltages drop occurred in the MFC stack, which were mainly limited by the cathodes. This loss of voltage indicates that the high IR the MFC stack generated a parasitic cross current. The voltage of $0.08-1.1 \mathrm{~V}$ in an OCV, COD removal of $74 \%, \mathrm{NH}_{4}-\mathrm{N}$ removal of $62 \%$ were obtained from individual MFC units. In series connection mode, a Pd of $2500 \mathrm{~mW} \mathrm{~m}^{-2}$, voltage of $4.9 \mathrm{~V}$, COD removal of $84 \%$ and $\mathrm{NH}_{4}-\mathrm{N}$ removal of $80 \%$ were obtained. In parallel connection, the Pd of $5.8 \mathrm{~mW} \mathrm{~m}^{-2}$, COD elimination of $78 \%$ and $\mathrm{NH}_{4}-\mathrm{N}$ removal of $73 \%$ were obtained [168]. Further, the power saving, low solids formation and high treatment efficiency are the major benefits of applying temperature-phased in MFC series configurations [169]. With temperature decline from $27.5^{\circ} \mathrm{C}$ to $8^{\circ} \mathrm{C}$ with mesophilic inoculum from a digester, MFC indicated strong proteolysis at low temperature compared to anaerobic digestion. The anaerobic digestion indicated a better performance at warmer situations. A lipases activity test indicated that hydrolyze lipids of anaerobic digestion and MFC were similar at $27.5^{\circ} \mathrm{C}$ and MFC indicated better lipolysis potential at low temperatures than anaerobic digestion. The switch from anaerobic digestion to MFC altered the microbial community by $15 \%$ where the MFC showed the maximum diversification. On the other hand, temperature drop can change the community by $40 \%$ [170].

Integration of MFC with other technologies for this kind of wastewater can be useful. In this regard, the effluent of an up-flow membrane-less MFC was used for feeding of photobioreactors. MFC alone generated Pdm of $481 \mathrm{mWm}^{-3}$. The COD removal of $77.9 \%$, total $\mathrm{P}$ removal of $23.5 \%$, and $\mathrm{NH}_{4}{ }^{+} \mathrm{N}$ removal of $97.6 \%$ were also obtained. On the other hand, when MFC combined with photobioreactor, $99.3 \%$ of total $\mathrm{P}$ and $99 \%$ of total $\mathrm{NH}_{4}{ }^{+}$-N were removed [171]. In another integrating, an algae biofilm with an MFC was integrated and the removal of total $\mathrm{N}$, total $\mathrm{P}$ and COD were obtained $96 \%, 91.5 \%$ and $80.2 \%$ respectively which was far superior to MFC or algae biofilm alone. The Pdm was obtained $62.93 \mathrm{~mW} \mathrm{~m}^{-2}$, which was $18 \%$ greater than when MFC was used alone $\left(52.33 \mathrm{~mW} \mathrm{~m}^{-2}\right)$. The CE was $17.01 \%$ and it is $36.7 \%$ higher than when MFC used alone (12.44\%). An energy of $0.094 \mathrm{kWh}$ $\mathrm{m}^{-3}$ was generated overall [172]. The new configurations with novelty for achieving better results or reducing investment cost are always encouraged. In this regard, different spacing of electrodes in some configurations with more than one anode and flow rates affect the current generation and COD removal. The MFC generated $0.22 \mathrm{kWh} \mathrm{kg-COD}^{-1}$ from low strength domestic wastewater by a flat-panel air-cathode MFC. This kind of MFC is well known for overcoming effluents with the low conductivity and biodegradability. Current generation was same at various spacing, although COD elimination was influenced by flow rates. According to the volume of effluent treated, the normalized energy recovery indicated a good correlation with the flow rates in entire anode different spacing. According to the COD elimination performance and apart from the anode different spacing, the normalized energy recovery indicated a negative correlation with the COD elimination rates [173] Given the importance of investment costs, an up-flow MFCs with polyvinylidene fluoridebased activated $\mathrm{C}$ air-cathode which is low cost, easy to configure and with higher stability for low strength wastewater. The average total COD removal rates of $5.11 \mathrm{~kg} \mathrm{COD} \mathrm{m}^{-3} \mathrm{~d}^{-1}$ and Pd of $3.96 \mathrm{~W}$ $\mathrm{m}^{-3}$ were obtained which were even greater than MFCs with Pt cathode. Also, high and steady suspended solid elimination $>90 \%$ was obtained without any clogging during the whole operation. In addition, a low voltage booster was applied to improve low voltage generation. The voltage rose from $<0.4 \mathrm{~V}$ to $4.35-5.2 \mathrm{~V}$ 
while there was no voltage reversal. It was adequate to drive three LED bulbs for $>12$ days [174].

\section{Urine}

The urine is a highly abundant waste product that forms part of municipal wastewater. The urine with a high concentration of organic compounds $\left(10 \mathrm{~g} \mathrm{l}^{-1}\right.$ of COD) mainly includes organic acids, N compounds, and carbohydrates [175]. Proper results have been achieved using raw or diluted urine in MFC. In this regard, an anaerobic microbial community, which was enriched with electroactive degrading urine microorganisms, was utilized. The Cd, Pd, COD removal, and CE during operation on undiluted urine were obtained as $495 \mathrm{~mA} \mathrm{~m}^{-2}, 306.5 \mathrm{~mW} \mathrm{~m}^{-2}, 75.5 \%$, and $26.5 \%$ respectively. In comparison to control group (without microbial enrichment), it was found that the addition of microbial acclimation resulted in elevated Cd production by $80 \%$. After 10 days of operation, most organic compounds were reduced except acetate [176]. During 45 days of operation in a SC-MFC with human raw urine, COD was degraded effectively with the COD elimination efficiency being $25-40 \%, 35-60 \%$, and $60-75 \%$ in 1 -day cycles, 2-day cycles, and 4-day cycles respectively [177]. Elsewhere, a large scale MFC with 64 units in two stacks was utilized. MFCs with a terracotta ceramic membrane were used, which formed with two stacks where each one had 32 individual units. By collecting the output current of 32 units in parallel connection and by adding the potential of 2 stacks in series connection for more than 120 days operation, an average $\mathrm{Pd}$ of $23 \mathrm{~mW} \mathrm{~m}^{-2}$ was generated with an efficient $\mathrm{Cd}$ of $65 \mathrm{~mA} \mathrm{~m}^{-2}$. In addition, COD removal of $70 \%$ was obtained in parallel connection of stacks, less than $50 \%$ in series connection of stacks and $80 \%$ when the stacks were separate [178].

The Struvite (magnesium ammonium phosphate$\mathrm{MgNH}_{4} \mathrm{PO}_{4} \cdot 6 \mathrm{H}_{2} \mathrm{O}$ ) is normally formed in the urine because of chemical reactions. Its recovery has two great benefits. The first is containing $\mathrm{N}$ and $\mathrm{P}$, which can simultaneously remove them and improve the quality of the effluents and the scond is reduction in operating costs. Further, it can cause reduced blockage of tubes in the wastewater treatment plants $[179,180]$. In addition, the struvite can be applied in the role of a slow-release fertilizer $[181,182]$. At such, an integrated system combining the struvite process with an MFC can recover P from the urine successfully and treat the urine [183]. The struvite precipitation mainly depends on the wastewater condition such as $\mathrm{pH}$ and ammonium level [184]. As an acceptor, the nitrate can be used in a cathode, which allows the concurrent elimination of $\mathrm{C}$ and $\mathrm{N}$ in the anode and cathode respectively [185]. In general, in the domestic wastewater, $\mathrm{N}$ is in $\mathrm{NH}_{4}^{+}$-N form; therefore aeration in MFCs is necessary for ammonium oxidation, nitrification, and denitrification [185]. The precipitation of struvite crystals increases in the urine via addition of magnesium. Several sources of magnesium, including $\mathrm{MgCl}_{2}$, synthetic sea water and a mixture of commercial sea salts are used for sea water preparation to be combined with real and fresh urine. Commercial sea water showed the best results in terms of struvite precipitation with the amount of struvite in the collected solids growing from $21 \%$ to $94 \%$. In addition, the sea water increased the maximum power efficiency of MFC by more than $10 \%$ and elevated $\mathrm{pH}$, conductivity, concentration of chloride ions, and it changed the properties of the collected catholyte [186]. A three-phase MFC system and the struvite extraction process were developed with two MFC groups used (each group containing 4 MFC units). In the first phase, the untreated urine was entered into the first MFCs group. MFCs improved the urea hydrolysis and it was useful for the struvite precipitation process in the second phase. In the second phase, the $\mathrm{MgCl}_{2}$ was added to the effluent of these MFCs and the struvite precipitation process was performed. In the third phase, the effluent was introduced into the second group of MFCs, after separating the struvite sediments. Using a three-phase system, $82 \%$ of $\mathrm{PO}_{4}{ }^{3}$-P and $20 \%$ of COD were eliminated from undiluted human urine. Also during the operation, $\mathrm{Pd}$ of $14.32 \mathrm{~W} \mathrm{~m}^{-3}$ at phase 1 and $11.76 \mathrm{~W} \mathrm{~m}^{-3}$ were obtained at phase 3 [187]. The results were appropriate when urine was treated by the MFC, as well as with integration of struvite process with MFC.

\section{Stool}

The human stool wastewater contains plentiful organic compounds. An automated MFC was designed operating with astronaut's stool on a day. It was used in MFC. When the DC-MFC operation was performed with real human stool wastewater for 190 hours, Pdm of $70.8 \mathrm{~mW} \mathrm{~m} \mathrm{~m}^{-2}$, COD removal of $71 \%$, soluble COD removal of $88 \%$, and $\mathrm{NH}_{4}^{+}$removal of $44 \%$ were obtained [188]. The pre-treatment is method useful for increasing the performance. For adjusting the $\mathrm{pH}$, the HRT was $5 \mathrm{~h}$. The Pdm of the MFC fed with pre-treated human stool was obtained $22 \mathrm{~mW}$ $\mathrm{m}^{-2}$. This was $47 \%$ higher than the non-pre-treatment control with a Pd of $15 \mathrm{~mW} \mathrm{~m}^{-2}$ [188]. Considering the configuration tips, which were mentioned, it was found that the capacity of electricity generation increased by enhancing electrode surface area and shortening the distance between the electrodes. The total power of $787.1 \mathrm{~mW}$ and Pdm of $240 \mathrm{~mW} \mathrm{~m}^{-2}$ were also obtained [188].

\section{Conclusion}

The community has completely recognized that the wastewater can be a valuable resource for energy generation and other compounds recovery, rather than a source of useless or harmful pollution. The MFCs have brought new opportunities as an emerging innovative technology. The MFCs apply organic compounds directly to produce energy. At the same time, they convert the substrate into electricity and treat the wastewater via their oxidation. Food industry wastewaters as a substrate meet most of the requirements of this technology in wastewater treatment. Note that due to the biological nature of the process, some parameters are determinant. In this regard, adjusting the temperature, pH, IR, HRT, OLR, conductivity and dissolved oxygen are very important. Each of them can affect the process with inhibitory effect. Sometimes pre-treatment is required for performance improvement or starting time reduction. Changes 
in designing are an appropriate method for performance improvement and investment cost reduction. Integration with the other technologies can also expand the implementation of MFCs on large scales of application. All these issues have been addressed in the text. With great progress, the output power of MFCs has increased significantly over the past decade which is due to scientific and technological advancements. However, this technology still has weaknesses to be recognized as an independent treatment and energy generation system.

Finally, more investigations should be performed to better understand the potential, stable MFCs' capability, answering to the challenges and identifying the future route. The MFC technology has not yet found its position on operational scales due to major challenges including high investment costs, important bottlenecks, increasing system scales, long-term operation, output power, energy recovery, microbial process and integrating. So far, good progresses have been made in all of these cases, but as MFC plays a significant role in the pattern of future changes of wastewater treatment and bioenergy production, more innovative research for improvement and better performance are required.

\section{References}

1. MC Potter (1911) Electrical Effects Accompanying the Decomposition of Organic Compounds. Proceedings of the Royal Society B: Biological Sciences 84: 260-276.

2. B Cohen (1931) J Bacteriol 21: 18-19.

3. I Karube, T Matsunaga, S Tsuru, S Suzuki (1976) Continous hydrogen production by immobilized whole cells of Clostridium butyricum. Biochim.Biophys Acta - Gen Subj 444(2): 338-343.

4. H P Bennetto (1990) Electricity generation by microorganisms Biotechnol Educ 1(4): 163-168.

5. HK Choi, TL Adams, RW Stahlhut, SI Kim, JH Yun, et al. (1999) Method for mass production of taxol by semi-continuous culture with Taxus chinensis cell culture. Google Patents.

6. TH Pham, K Rabaey, P Aelterman, P Clauwaert, L, et al. (2006) Microbial Fuel Cells in Relation to Conventional Anaerobic Digestion Technology. Eng Life Sci 6(3): 285-292.

7. Z Du, H Li, T Gu (2007) A state of the art review on microbial fuel cells: A promising technology for wastewater treatment and bioenergy. Biotechnol Adv 25(5): 464-482.

8. D Pant, G Van Bogaert, L Diels, K Vanbroekhoven (2010) A review of the substrates used in microbial fuel cells (MFCs) for sustainable energy production. Bioresour Technol 101(6): 1533-1543.

9. P Aelterman, K Rabaey, P Clauwaert, W Verstraete (2006) Microbial fuel cells for wastewater treatment. Water Sci Technol 54(8): 9-15.

10. P Clauwaert, K Rabaey, P Aelterman, L De Schamphelaire, TH Pham, et al. (2007) Biological Denitrification in Microbial Fuel Cells. Environ Sci Technol 41(9): 3354-3360.

11. B Zhang, Z Wang, X Zhou, C Shi, H Guo, et al. (2015) Electrochemical decolorization of methyl orange powered by bioelectricity from singlechamber microbial fuel cells. Bioresour Technol 181: 360-362.

12. P Pandey, VN Shinde, RL Deopurkar, SP Kale, SA Patil, et al. (2016) Recent advances in the use of different substrates in microbial fuel cells toward wastewater treatment and simultaneous energy recovery. Appl Energy 168: 706-723.

13. L Petrus, MA Noordermeer (2006) Biomass to biofuels, a chemical perspective. Green Chem 8(10): 861-867.

14.M Rahimnejad, AA Ghoreyshi, GD Najafpour, H Younesi, M Shaker (2012) A novel microbial fuel cell stack for continuous production of clean energy. Int J Hydrogen Energy 37(7): 5992-6000.

15. T Catal, K Li, H Bermek, H Liu (2008) Electricity production from twelve monosaccharides using microbial fuel cells. J Power Sources 175(1): 196-200.

16. K Rabaey, N Boon, SD Siciliano, M Verhaege, W Verstraete (2020) Biofuel Cells Select for Microbial Consortia That Self-Mediate Electron Transfer. Appl Environ Microbiol 70(9).

17. J Choi, HN Chang, JI (2011) Performance of microbial fuel cell with volatile fatty acids from food wastes. Han Biotechnol Lett 33: 705-714.

18. M Hosseinpour, M Asadi, TR Eliato, M Vossoughi, I Alemzadeh (2016) Ethylene glycol biodegradation in microbial fuel cell. Energy Sources, Part A Recover Util Environ Eff 38(8): 1096-1102.

19. D Pant, D Arslan, G Van Bogaert, YA Gallego, H De Wever, et al. (2013) Integrated conversion of food waste diluted with sewage into volatile fatty acids through fermentation and electricity through a fuel cell. Environ Technol 34(13-14): 1935-1945.

20. JR Kim, SH Jung, JM Regan, BE Logan (2007) Electricity generation and microbial community analysis of alcohol powered microbial fuel cells. Bioresour Technol 98(13): 2568-2577.

21. T Catal, S Xu, K Li, H Bermek, H Liu (2008) Electricity generation from polyalcohols in single-chamber microbial fuel cells. Biosens Bioelectron 24(4): 849-854.

22. F Li, C Yin, L Sun, Y Li, X Guo, H Song (2017) Synthetic Klebsiella pneumoniae-Shewanella oneidensis Consortium Enables Glycerol-Fed High-Performance Microbial. Fuel Cells Biotechnol J 13(5): 1700491.

23. B Min, BE Logan (2004) Continuous Electricity Generation from Domestic Wastewater and Organic Substrates in a Flat Plate Microbial Fuel Cell. Environ Sci Technol 38(21): 5809-5814.

24. HS Lee, P Parameswaran, A Kato-Marcus, CI Torres, BE Rittmann (2008) Evaluation of energy-conversion efficiencies in microbial fuel cells (MFCs) utilizing fermentable and non-fermentable substrates. Water Res 42(6-7): 1501-1510.

25. H Liu, S Cheng, BE Logan (2005) Production of Electricity from Acetate or Butyrate Using a Single-Chamber Microbial Fuel Cell. Environ Sci Technol 39(2): 658-662.

26. JY Nam, HW Kim, KH Lim, HS Shin (2010) Effects of organic loading rates on the continuous electricity generation from fermented wastewater using a single-chamber microbial fuel cell. Bioresour Technol 101(1 Suppl): S33-S37.

27.SM Ahmed, E Rozaik, H Abdelhalim, (2016) Performance of SingleChamber Microbial Fuel Cells Using Different Carbohydrate-Rich Wastewaters and Different Inocula. Polish J Environ Stud 25(2): 503510 .

28. CH Wu, YP I, YH Chiu, CW Lin (2014) Enhancement of power generation by toluene biodegradation in a microbial fuel cell in the presence of pyocyanin. J Taiwan Inst Chem Eng 45(5): 2319-2324.

29. ANZ Al-Shehri (2015) Employment of microbial fuel cell technology to biodegrade naphthalene and benzidine for bioelectricity generation. Int J Curr Microbiol Appl Sci 4(1): 134-139.

30. VR Nimje, CY Chen, CC Chen, HR Chen, MJ Tseng, et al. (2011) Glycerol degradation in single-chamber microbial fuel cells. Bioresour Technol 102(3): 2629-2634.

31. A Tremouli, T Vlassis, G Antonopoulou, G Lyberatos (2016) Anaerobic Degradation of Pure Glycerol for Electricity Generation using a MFC: The Effect of Substrate Concentration. Waste and Biomass Valorization $7: 1339-1347$ 
32. T Chookaew, P Prasertsan, ZJ Ren (2014) Two-stage conversion of crude glycerol to energy using dark fermentation linked with microbial fuel cell or microbial electrolysis cell. N Biotechnol 31(2): 179-184.

33. NJ Beecroft, F Zhao, JR Varcoe, RCT Slade, AE Thumser, et al. (2012) Dynamic changes in the microbial community composition in microbial fuel cells fed with sucrose. Appl Microbiol Biotechnol 93: 423-437.

34. Q Yang, X Wang, Y Feng, H Lee, J Liu, et al. (2012) Electricity generation using eight amino acids by air-cathode microbial fuel cells. Fuel 102: 478-482.

35. H Li, Y Tian, W Zuo, J Zhang, X Pan, et al. (2016) Electricity generation from food wastes and characteristics of organic matters in microbial fuel cell. Bioresour Technol 205: 104-110.

36. J Heilmann, BE Logan (2006) Production of Electricity from Proteins Using a Microbial Fuel Cell. Water Environ Res 78(5): 531-537.

37. BE Logan, C Murano, K Scott, ND Gray, IM Head (2005) Electricity generation from cysteine in a microbial fuel cell. Water Res 39(5): 942 952

38. CP Yu, Z Liang, A Das, Z Hu (2011) Nitrogen removal from wastewater using membrane aerated microbial fuel cell techniques. Water Res 45(3): 1157-1164.

39. S Xie, P Liang, Y Chen, X Xia, X Huang (2011) Simultaneous carbon and nitrogen removal using an oxic/anoxic-biocathode microbial fuel cells coupled system. Bioresour Technol 102(1): 348-354.

40.Z Chen, S Zhang, L Zhong (2019) Simultaneous sulfide removal, nitrogen removal and electricity generation in a coupled microbial fuel cell system. Bioresour Technol 291: 121888.

41. Y Li, I Williams, Z Xu, B Li, B Li (2016) Energy-positive nitrogen removal using the integrated short-cut nitrification and autotrophic denitrification microbial fuel cells (MFCs). Appl Energy 163: 352-360.

42. A Vijay, M Vaishnava, M Chhabra (2016) Microbial fuel cell assisted nitrate nitrogen removal using cow manure and soil. Environ Sci Pollut Res 23: 7744-7756.

43. A Al-Mamun, T Jafary, MS Baawain, S Rahman, MR Choudhury, et al. (2020) Energy recovery and carbon/nitrogen removal from sewage and contaminated groundwater in a coupled hydrolytic-acidogenic sequencing batch reactor and denitrifying biocathode microbial fuel cell. Environ Res 183: 109273.

44. L van Niftrik, MSM Jetten (2012) Anaerobic Ammonium-Oxidizing Bacteria: Unique Microorganisms with Exceptional Properties. Microbiol Mol Biol Rev 76(3).

45. Y Guo, X Wei, S Zhang (2020) Simultaneous removal of organics, sulfide and ammonium coupled with electricity generation in a loop microbial fuel cell system. Bioresour Technol 305: 123082.

46. A Cucu, A Tiliakos, I Tanase, CE Serban, I Stamatin, et al. (2016) Microbial Fuel Cell for Nitrate Reduction. Energy Procedia 85: 156161.

47. AM Silva, RMF Lima, VA Leão (2012) Mine water treatment with limestone for sulfate removal. J Hazard Mater 221-222: 45-55.

48. A Wang, C Liu, N Ren, H Han, D Lee (2010) Simultaneous removal of sulfide, nitrate and acetate: Kinetic modeling. J Hazard Mater 178(13): $35-41$

49. J Jiang, Q Zhao, J Zhang, G Zhang, DJ Lee (2009) Electricity generation from bio-treatment of sewage sludge with microbial fuel cell. Bioresour Technol 100(23): 5808-5812.

50. DJ Lee, X Liu, HL Weng (2014) Sulfate and organic carbon removal by microbial fuel cell with sulfate-reducing bacteria and sulfide-oxidising bacteria anodic biofilm. Bioresour Technol 156: 14-19.

51. DJ Lee, CY Lee, JS Chang (2021) Treatment and electricity harvesting from sulfate/sulfide-containing wastewaters using microbial fuel cell with enriched sulfate-reducing mixed culture. J Hazard Mater 243: 6772.

52.X Xu, C Chen, DJ Lee, A Wang, W Guo, et al. (2013) Sulfate-reduction, sulfide-oxidation and elemental sulfur bioreduction process: Modeling and experimental validation. Bioresour Technol 147: 202-211.

53.X Xu, C Chen, A Wang, W Guo, X Zhou, et al. (2014) Simultaneous removal of sulfide, nitrate and acetate under denitrifying sulfide removal condition: Modeling and experimental validation. J Hazard Mater 264: 16-24.

54. C Chen, KL Ho, FC Liu, M Ho, A Wang, et al. (2013) Autotrophic and heterotrophic denitrification by a newly isolated strain Pseudomonas sp. C27. Bioresour Technol 145: 351-356.

55. KY Show, DJ Lee, X Pan (2013) Simultaneous biological removal of nitrogen-sulfur-carbon: Recent advances and challenges. Biotechnol Adv 31(4): 409-420.

56. H Liu, B Zhang, Y Liu, Z Wang, L Hao (2015) Continuous bioelectricity generation with simultaneous sulfide and organics removals in an anaerobic baffled stacking microbial fuel cell. Int J Hydrogen Energy 40(25): 8128-8136.

57. U Abbasi, W Jin, A Pervez, ZA Bhatti, M Tariq, S Shaheen, et al. (2016) Anaerobic microbial fuel cell treating combined industrial wastewater: Correlation of electricity generation with pollutants. Bioresour Technol 200: 1-7.

58. S Fatemi, AA Ghoreyshi, M Rahimnejad, GN Darzi, D Pant (2017) Sulfide as an alternative electron donor to glucose for power generation in mediator-less microbial fuel cell. J Environ Sci Heal Part A 52(12): 1150-1157.

59. S Bratkova, Z Alexieva, A Angelov, K Nikolova, P Genova, et al. (2019) Efficiency of microbial fuel cells based on the sulfate reduction by lactate and glucose. Int J Environ Sci Technol 16: 6145-6156.

60. M Yang, Y Zhong, B Zhang, J Shi, X Huang, et al. (2018) Enhanced sulfide removal and bioelectricity generation in microbial fuel cells with anodes modified by vertically oriented nanosheets. Environ Technol 40(14): 1770-1779.

61.SS Kumar, V Kumar, V Gnaneswar Gude, SK Malyan, A Pugazhendhi (2020) Alkalinity and salinity favor bioelectricity generation potential of Clostridium, Tetrathiobacter and Desulfovibrio consortium in Microbial Fuel Cells (MFC) treating sulfate-laden wastewater. Bioresour Technol 306: 123110.

62. F Zhao, N Rahunen, JR Varcoe, A Chandra, C Avignone-Rossa, et al. (2008) Activated Carbon Cloth as Anode for Sulfate Removal in a Microbial Fuel Cell. Environ Sci Technol 42(13): 4971-4976.

63. M Hemalatha, J Shanthi Sravan, S Venkata Mohan (2020) Self-induced bioelectro-potential influence on sulfate removal and desalination in microbial fuel cell. Bioresour Technol 309: 123326.

64. Q Tao, J Luo, J Zhou, S Zhou, G Liu, et al. (2014) Effect of dissolved oxygen on nitrogen and phosphorus removal and electricity production in microbial fuel cell. Bioresour Technol 164: 402-407.

65. L Doherty, Y Zhao, X Zhao, W Wang (2015) Nutrient and organics removal from swine slurry with simultaneous electricity generation in an alum sludge-based constructed wetland incorporating microbial fuel cell technology. Chem Eng J 266: 74-81.

66. O Ichihashi, K Hirooka (2012) Removal and recovery of phosphorus as struvite from swine wastewater using microbial fuel cell. Bioresour Technol 114: 303-307.

67. F Fischer, C Bastian, M Happe, E Mabillard, N Schmidt (2011) Microbial fuel cell enables phosphate recovery from digested sewage sludge as struvite. Bioresour Technol 102(10): 5824-5830. 
68. XWang, Y Tian, H Liu, XZhao, S Peng (2019) Optimizing the performance of organics and nutrient removal in constructed wetland-microbial fuel cell systems. Sci Total Environ 653: 860-871.

69. Y Wang, Z Lin, Y Wang, W Huang, J Wang, et al. (2019) Sulfur and iron cycles promoted nitrogen and phosphorus removal in electrochemically assisted vertical flow constructed wetland treating wastewater treatment plant effluent with high $\mathrm{S} / \mathrm{N}$ ratio. Water Res 151: $20-30$.

70. X Ge, X Cao, X Song, Y Wang, Z Si, et al. (2020) Bioenergy generation and simultaneous nitrate and phosphorus removal in a pyrite-based constructed wetland-microbial fuel cell. Bioresour Technol 296: 122350.

71. Z Kong, L Li, C Feng, S Dong, N Chen (2016) Comparative investigation on integrated vertical-flow biofilters applying sulfur-based and pyritebased autotrophic denitrification for domestic wastewater treatment. Bioresour Technol 211: 125-135.

72. SK Han, SH Kim, HS Shin (2005) UASB treatment of wastewater with VFA and alcohol generated during hydrogen fermentation of food waste. Process Biochem 40(8): 2897-2905

73. AA Tatsi, AI Zouboulis (2002) A field investigation of the quantity and quality of leachate from a municipal solid waste landfill in a Mediterranean climate (Thessaloniki, Greece). Adv Environ Res 6(3): 207-219.

74. Y Chen, JJ Cheng, KS Creamer (2008) Inhibition of anaerobic digestion process: A review. Bioresour Technol 99(10): 4044-4064.

75. XM Li, KY Cheng, A Selvam, JWC Wong (2013) Bioelectricity production from acidic food waste leachate using microbial fuel cells: Effect of microbial inocula. Process Biochem 48(2): 283-288.

76. PV Moharir, AR Tembhurkar (2018) Effect of recirculation on bioelectricity generation using microbial fuel cell with food waste leachate as substrate. Int J Hydrogen Energy 43(21): 10061-10069.

77. SS Rikame, AA Mungray, AK Mungray (2021) Electricity generation from acidogenic food waste leachate using dual chamber mediator less microbial fuel cell. Int Biodeterior Biodegradation 75: 131-137.

78. EV Ramasamy, SA Abbasi (2000) Energy recovery from dairy wastewaters: impacts of biofilm support systems on anaerobic CST reactors Appl Energy 64(1-4): 91-98.

79. SV Mohan, VL Babu, PN Sarma (2007) Anaerobic biohydrogen production from dairy wastewater treatment in sequencing batch reactor (AnSBR): Effect of organic loading rate. Enzyme Microb Technol 41(4): 506-515.

80. RJ Marassi, LG Queiroz, DCVR Silva, FT da Silva, GC Silva, et al. (2020) Performance and toxicity assessment of an up-flow tubular microbial fuel cell during long-term operation with high-strength dairy wastewater. J Clean Prod 259: 120882.

81. A Faria, L Gonçalves, JM Peixoto, L Peixoto, AG Brito, et al. (2017) Resources recovery in the dairy industry: bioelectricity production using a continuous microbial fuel cell. J Clean Prod 140(Part 2): 971976

82. AD Sekar, T Jayabalan, H Muthukumar, NI Chandrasekaran, SN Mohamed, et al. (2019) Enhancing power generation and treatment of dairy waste water in microbial fuel cell using $\mathrm{Cu}$-doped iron oxide nanoparticles decorated anode. Energy 172: 173-180.

83. B Cercado-Quezada, ML Delia, A Bergel (2010) Testing various foodindustry wastes for electricity production in microbial fuel cell. Bioresour Technol 101(8): 2748-2754.

84. H Luo, G Xu, Y Lu, G Liu, R Zhang, X Li, et al. (2017) Electricity generation in a microbial fuel cell using yogurt wastewater under alkaline conditions. RSC Adv 7: 32826-32832.
85. J Gelegenis, D Georgakakis, I Angelidaki, V Mavris (2007) Optimization of biogas production by co-digesting whey with diluted poultry manure. Renew Energy 32(13): 2147-2160.

86. J Kassongo, CA Togo (2011) Performance improvement of whey-driven microbial fuel cells by acclimation of indigenous anodophilic microbes. African J Biotechnol 10(40): 7846-7852.

87. M Ghasemi, A Ahmad, T Jafary, AK Azad, S Kakooei, et al. (2017) Assessment of immobilized cell reactor and microbial fuel cell for simultaneous cheese whey treatment and lactic acid/electricity production. Int J Hydrogen Energy 42(14): 9107-9115.

88. G Antonopoulou, I Ntaikou, S Bebelis, G Lyberatos (2020) On the evaluation of filtered and pretreated cheese whey as an electron donor in a single chamber microbial fuel cell. Biomass Convers. Biorefinery 11: 633-643.

89. J Wenzel, L Fuentes, A Cabezas, C Etchebehere (2017) Microbial fuel cell coupled to biohydrogen reactor: a feasible technology to increase energy yield from cheese whey. Bioprocess Biosyst Eng 40: 807-819.

90.W Miran, M Nawaz, J Jang, DS Lee (2016) Conversion of orange peel waste biomass to bioelectricity using a mediator-less microbial fuel cell. Sci Total Environ 547: 197-205.

91.W Miran, M Nawaz, J Jang, DS Lee (2016) Sustainable electricity generation by biodegradation of low-cost lemon peel biomass in a dual chamber microbial fuel cell. Int Biodeterior Biodegradation 106: 7579.

92. AG del Campo, JF Perez, P Cañizares, MA Rodrigo, FJ Fernandez, et al. (2014) Study of a photosynthetic MFC for energy recovery from synthetic industrial fruit juice wastewater. Int J Hydrogen Energy 39(36): 21828-21836.

93. A Divya Priya, Y Pydi Setty (2019) Cashew apple juice as substrate for microbial fuel cell. Fuel 246: 75-78.

94. A ElMekawy, S Srikanth, S Bajracharya, HM Hegab, PS Nigam, etal. (2015) Food and agricultural wastes as substrates for bioelectrochemical system (BES): The synchronized recovery of sustainable energy and waste treatment. Food Res Int 73: 213-225.

95. Y Feng, X Wang, BE Logan, H Lee (2008) Brewery wastewater treatment using air-cathode microbial fuel cells. Appl Microbiol Biotechnol 78: 873-880.

96.L Zhuang, C Feng, S Zhou, Y Li, Y Wang (2010) Comparison of membrane- and cloth-cathode assembly for scalable microbial fuel cells: Construction, performance and cost. Process Biochem 45(6): 929-934.

97. L Zhuang, Y Yuan, Y Wang, S Zhou (2012) Long-term evaluation of a 10-liter serpentine-type microbial fuel cell stack treating brewery wastewater. Bioresour Technol 123: 406-412.

98. M Lu, S Chen, S Babanova, S Phadke, M Salvacion, et al. (2017) Longterm performance of a 20-L continuous flow microbial fuel cell for treatment of brewery wastewater. J Power 356: 274-287.

99. J Liu, C Tian, X Jia, J Xiong, S Dong, et al. (2017) The brewery wastewater treatment and membrane fouling mitigation strategies in anaerobic baffled anaerobic/aerobic membrane bioreactor. Biochem Eng J 127: 53-59.

100. ED Penteado, CM Fernandez-Marchante, M Zaiat, P Cañizares, ER Gonzalez, et al. (2016) Energy recovery from winery wastewater using a dual chamber microbial fuel cell. J Chem Technol Biotechnol 91(6): 1802-1808.

101. TP Sciarria, G Merlino, B Scaglia, AD’Epifanio, B Mecheri, et al. (2015) Electricity generation using white and red wine lees in air cathode microbial fuel cells. J Power Sources 274: 393-399. 
102. QF Alsalhy, RS Almukhtar, HA Alani (2016) Oil Refinery Wastewater Treatment by Using Membrane Bioreactor (MBR). Arab J Sci Eng 41: $2439-2452$

103. S Munirasu, MA Haija, F Banat (2016) Use of membrane technology for oil field and refinery produced water treatment-A review. Process Saf Environ Prot 100: 183-2020.

104. AF Viero, TM de Melo, APR Torres, NR Ferreira, GLS Jr, et al. (2008) The effects of long-term feeding of high organic loading in a submerged membrane bioreactor treating oil refinery wastewater. J Memb Sci 319(1-2): 223-30.

105. N Yu, D Xing, W Li, Y Yang, Z Li, et al. (2017) Electricity and methane production from soybean edible oil refinery wastewater using microbial electrochemical systems. Int J Hydrogen Energy 42(1): 96102

106. S Firdous, W Jin, N Shahid, ZA Bhatti, A Iqbal, et al. (2018) The performance of microbial fuel cells treating vegetable oil industrial wastewater. Environ Technol Innov 10: 143-151.

107. M Karhu, T Leiviskä, J Tanskanen (2014) Enhanced DAF in breaking up oil-in-water emulsions. Sep Purif Technol 122: 231-241.

108. H Bermek, T Catal, SS Akan, MS Uluta, M Kumru, et al. (2014) Olive mill wastewater treatment in single-chamber air-cathode microbial fuel cells. World J Microbiol Biotechnol 30: 1177-1185.

109. SJ Santosa (2008) Palm Oil Boom in Indonesia: From Plantation to Downstream Products and Biodiesel. CLEAN - Soil, Air, Water 36(56): 453-465.

110. E Baranitharan, MR Khan, DMR Prasad, J Bin Salihon (2013) Bioelectricity Generation from Palm Oil Mill Effluent in Microbial Fuel Cell Using Polacrylonitrile Carbon Felt as Electrode. Water, Air, Soil Pollut 224: 1533.

111. E Baranitharan, MR Khan, A Yousuf, WFA Teo, GYA Tan, et al. (2015) Enhanced power generation using controlled inoculum from palm oil mill effluent fed microbial fuel cell. Fuel 143: 72-79.

112. MHM Nor, MFM Mubarak, HAS Elmi, N Ibrahim, MFA Wahab, et al. (2015) Bioelectricity generation in microbial fuel cell using natural microflora and isolated pure culture bacteria from anaerobic palm oil mill effluent sludge. Bioresour Technol 190: 458-465.

113. SP Tan, HF Kong, MJK Bashir, PK Lo, CD Ho, et al. (2017) Treatment of palm oil mill effluent using combination system of microbial fuel cell and anaerobic membrane bioreactor. Bioresour Technol 245(Part A): 916-924.

114. J Cheng, X Zhu, J Ni, A Borthwick (2010) Palm oil mill efflux: ent treatment using a two-stage microbial fuel cells system integrated with immobilized biological aerated filters. Bioresour Technol 101(8): 2729-2734.

115. EP Leaño, AJ Anceno, S Babel (2012) Ultrasonic pretreatment of palm oil mill effluent: Impact on biohydrogen production, bioelectricity generation, and underlying microbial communities. Int J Hydrogen Energy 37(17): 12241-12249.

116. B Jin, XQ Yan, Q Yu, JH van Leeuwen (2002) A comprehensive pilot plant system for fungal biomass protein production and wastewater reclamation. Adv Environ Res 62(2): 179-189.

117. M Uno, N Phansroy, Y Aso, H Ohara (2017) Starch-fueled microbial fuel cells by two-step and parallel fermentation using Shewanella oneidensis MR-1 and Streptococcus bovis 148. J Biosci Bioeng 124(2): 189-194.

118. C Zhong, B Zhang, L Kong, A Xue, J Ni (2011) Electricity generation from molasses wastewater by an anaerobic baffled stacking microbial fuel cell. J Chem Technol Biotechnol 86(3): 406-413.
119. S Pandit, G Balachandar, D Das (2014) Improved energy recovery from dark fermented cane molasses using microbial fuel cells. Front Chem Sci Eng 8: 43-54.

120. B Zhang, H Zhao, S Zhou, C Shi, C Wang, et al. (2009) A novel UASBMFC-BAF integrated system for high strength molasses wastewater treatment and bioelectricity generation. Bioresour Technol 100(23): 5687-5693.

121. N Samsudeen, TK Radhakrishnan, M Matheswaran (2015) Bioelectricity production from microbial fuel cell using mixed bacterial culture isolated from distillery wastewater. Bioresour Technol 195: 242-247.

122. S Naina Mohamed, R Thota Karunakaran, M Manickam (2018) Enhancement of bioelectricity generation from treatment of distillery wastewater using microbial fuel cell. Environ Prog Sustain Energy 37(2): 663-668.

123. YY Lee, TG Kim, KS Cho (2016) Characterization of the COD removal, electricity generation, and bacterial communities in microbial fuel cells treating molasses wastewater. J Environ Sci Heal Part A 51(13): 1131-1138.

124. SA Patil, VP Surakasi, S Koul, S Ijmulwar, A Vivek, et al. (2009) Electricity generation using chocolate industry wastewater and its treatment in activated sludge based microbial fuel cell and analysis of developed microbial community in the anode chamber. Bioresour Technol 100(21): 5132-5139.

125. P Noori, G Najafpour Darzi (2016) Enhanced power generation in annular single-chamber microbial fuel cell via optimization of electrode spacing using chocolate industry wastewater. Biotechnol Appl Biochem 63(3): 427-434.

126. P Nouri, G Najafpour Darzi (2017) Impacts of process parameters optimization on the performance of the annular single chamber microbial fuel cell in wastewater treatment. Eng Life Sci 17(5): 545551.

127. HJ Mansoorian, AH Mahvi, AJ Jafari, MM Amin, A Rajabizadeh, et al. (2013) Bioelectricity generation using two chamber microbial fuel cell treating wastewater from food processing. Enzyme Microb Technol 52(6-7): 352-357.

128. S Oh, BE Logan (2005) Hydrogen and electricity production from a food processing wastewater using fermentation and microbial fuel cell technologies. Water Res 39(17): 4673-4682.

129. A Fogg, V Gadhamshetty, D Franco, J Wilder, S Agapi, et al. (2015) Can a microbial fuel cell resist the oxidation of Tomato pomace? Power Sources 279: 781-790.

130. JS Smith, YH Hui (2004) Food processing: principles and applications. Black Well, IOWA, USA.

131. C Jayashree, K Tamilarasan, M Rajkumar, P Arulazhagan, KN Yogalakshmi, et al. (2016) Treatment of seafood processing wastewater using upflow microbial fuel cell for power generation and identification of bacterial community in anodic biofilm. J Environ Manage 180: 351-358.

132. SJ You, JN Zhang, YXYuan, NQ Ren, XH Wang et al. (2010) Development of microbial fuel cell with anoxic/oxic design for treatment of saline seafood wastewater and biological electricity generation. J Chem Technol Biotechnol 85(8): 1077-1083.

133. C Sukkasem, S Laehlah (2013) Development of a UBFC biocatalyst fuel cell to generate power and treat industrial wastewaters. Bioresour Technol 146: 749-753.

134. F Guo, G Fu, Z Zhang, C Zhang (2013) Mustard tuber wastewater treatment and simultaneous electricity generation using microbial fuel cells. Bioresour Technol 136: 425-430. 
135. F Guo, G Fu, Z Zhang (2015) Performance of mixed-species biocathode microbial fuel cells using saline mustard tuber wastewater as selfbuffered catholyte. Bioresour Technol 180: 137-143.

136. SV Mohan, G Mohanakrishna, PN Sarma (2010) Composite vegetable waste as renewable resource for bioelectricity generation through non-catalyzed open-air cathode microbial fuel cell. Bioresour Technol 101(3): 970-976.

137. SV Mohan, K Chandrasekhar (2011) Solid phase microbial fuel cell (SMFC) for harnessing bioelectricity from composite food waste fermentation: Influence of electrode assembly and buffering capacity. Bioresour Technol 102(14): 7077-085.

138. ZJ Wang, BS Lim (2017) Environ Eng Res.

139. HJ Mansoorian, AH Mahvi, AJ Jafari, N Khanjani (2016) Evaluation of dairy industry wastewater treatment and simultaneous bioelectricity generation in a catalyst-less and mediator-less membrane microbial fuel cell. J Saudi Chem Soc 20(1): 88-100.

140. P Choudhury, RN Ray, TK Bandyopadhyay, B Bhunia (2020) Fed batch approach for stable generation of power from dairy wastewater using microbial fuel cell and its kinetic study. Fuel 266: 117073.

141. S Sanjay, TH Udayashankara (2020) Dairy wastewater treatment with bio-electricity generation using dual chambered membraneless microbial fuel cell. Mater Today Proc 35(Part 3): 308-311.

142. RJ Marassi, LG Queiroz, DCVR Silva, FS dos Santos, GC Silva, et al. (2020) Long-term performance and acute toxicity assessment of scaled-up air-cathode microbial fuel cell fed by dairy wastewater Bioprocess Biosyst Eng 43: 1561-1571.

143. A Tremouli, G Antonopoulou, S Bebelis, G Lyberatos (2013) Operation and characterization of a microbial fuel cell fed with pretreated cheese whey at different organic loads. Bioresour Technol 131: 380389 .

144. G Mohanakrishna, IM Abu Reesh, RI lRaoush, Z He (2018) Cylindrical graphite based microbial fuel cell for the treatment of industrial wastewaters and bioenergy generation. Bioresour Technol 247: 753758.

145. S Kondaveeti, G Mohanakrishna, A Kumar, C Lai, JK Lee, VC Kalia (2019) Exploitation of Citrus Peel Extract as a Feedstock for Power Generation in Microbial Fuel Cell (MFC). Indian J Microbiol 59: 476481.

146. AJT Harewood, SR Popuri, EI Cadogan, CH Lee, CC Wang (2017) Bioelectricity generation from brewery wastewater in a microbial fuel cell using chitosan/biodegradable copolymer membrane. Int J Environ Sci Technol 14: 1535-1550.

147. ED Penteado, CM Fernandez Marchante, M Zaiat, ER Gonzalez, MA Rodrigo (2017) Influence of carbon electrode material on energy recovery from winery wastewater using a dual-chamber microbial fuel cell. Environ Technol 38(11): 1331-1341.

148. ED Penteado, CM Fernandez Marchante, M Zaiat, P Cañizares, ER Gonzalez (2016) Influence of sludge age on the performance of MFC treating winery wastewater. Chemosphere 151: 163-170.

149. J Lee, CA Ng, PK Lo, MJK Bashir (2019) Enhancement of renewable electrical energy recovery from palm oil mill effluent by microbial fuel cell with activated carbon. Energy Sources, Part A Recover Util Environ Eff 41(21): 2662-2674.

150. N Lu, S Zhou, L Zhuang, J Zhang, J Ni (2009) Electricity generation from starch processing wastewater using microbial fuel cell technology. Biochem Eng J 43(3): 246-251.

151. SHA Hassan, A el Nasser A Zohri, RMF Kassim (2019) Electricity generation from sugarcane molasses using microbial fuel cell technologies. Energy 178: 538-543.
152. CH Wu, SH Liu, HL Chu, YC Li, CW Lin (2017) Feasibility study of electricity generation and organics removal for a molasses wastewater by a waterfall-type microbial fuel cell. J Taiwan Inst Chem Eng 78: 150-156.

153. T Song, X Wu, CC Zhou (2014) Effect of different acclimation methods on the performance of microbial fuel cells using phenol as substrate. Bioprocess Biosyst Eng 37: 133-138.

154. C Jayashree, P Arulazhagan, SA Kumar, S Kaliappan, IT Yeom, et al. (2014) Bioelectricity generation from coconut husk retting wastewater in fed batch operating microbial fuel cell by phenol degrading microorganism. Biomass and Bioenergy 69: 249-254.

155. C Feng, L Huang, H Yu, X Yi, C Wei (2015) Simultaneous phenol removal, nitrification and denitrification using microbial fuel cell technology. Water Res 76: 160-170.

156. WK Kirui, S Wu, S Kizito, PN Carvalho, R Dong (2016) Pathways of nitrobenzene degradation in horizontal subsurface flow constructed wetlands: Effect of intermittent aeration and glucose addition. Environ Manage 166: 38-44.

157. E Zhang, F Wang, W Zhai, K Scott, X Wang, et al. (2017) Efficient removal of nitrobenzene and concomitant electricity production by single-chamber microbial fuel cells with activated carbon aircathode. Bioresour Technol 229: 111-118.

158. T Xie, Z Jing, J Hu, P Yuan, Y Liu, et al. (2018) Degradation of nitrobenzene-containing wastewater by a microbial-fuel-cellcoupled constructed wetland. Ecol Eng 112: 65-71.

159. H Hassan, B Jin, S Dai, T Ma, C Saint (2016) Chemical impact of catholytes on Bacillus subtilis-catalysed microbial fuel cell performance for degrading 2,4-dichlorophenol. Chem Eng J 301: 103-114.

160. L Di, Y Li, L Nie, S Wang, F Kong (2020) Influence of plant radial oxygen loss in constructed wetland combined with microbial fuel cell on nitrobenzene removal from aqueous solution. J Hazard Mater 394: 122542 .

161. SK Beher, JM Park, KH Kim, HS Park (2010) Methane production from food waste leachate in laboratory-scale simulated landfill. Waste Manag 30(8-9): 1502-1508.

162. J Gustavsson, C Cederberg, U Sonesson, R Van Otterdijk, A Meybeck (2011) Global food losses and food waste. Food and Agriculture organization of the United Nations Publishing, Rome.

163. ES Heidrich, TP Curtis, J Dolfing (2011) Determination of the Internal Chemical Energy of Wastewater. Environ Sci Technol 45(2): 827-832.

164. H Hiegemann, D Herzer, E Nettmann, M Lübken, P Schulte, et al (2016) An integrated $45 \mathrm{~L}$ pilot microbial fuel cell system at a fullscale wastewater treatment plant. Bioresour Technol 218: 115-122.

165. Y Feng, W He, J Liu, X Wang, Y Qu, et al. (2014) A horizontal plug flow and stackable pilot microbial fuel cell for municipal wastewater treatment. Bioresour Technol 156: 132-138.

166. Z Ge, L Wu, F Zhang, Z He (2015) Energy extraction from a large-scale microbial fuel cell system treating municipal wastewater. J Power Sources 297: 260-264.

167. P Liang, R Duan, Y Jiang, X Zhang, Y Qiu, X Huang (2018) One-year operation of 1000-L modularized microbial fuel cell for municipal wastewater treatment. Water Res 141: 1-8.

168. EB Estrada Arriaga, J Hernández Romano, L García Sánchez, RAG Garcés, EO Bahena Bahena, et al. (2018) Domestic wastewater treatment and power generation in continuous flow air-cathode stacked microbial fuel cell: Effect of series and parallel configuration. J Environ Manage 214: 232-241. 
169. Y Ahn, BE Logan (2010) Effectiveness of domestic wastewater treatment using microbial fuel cells at ambient and mesophilic temperatures. Bioresour Technol 101(2): 469-475.

170. E Petropoulos, B Shamurad, K Acharya, S Tabraiz (2020) Domestic wastewater hydrolysis and lipolysis during start-up in anaerobic digesters and microbial fuel cells at moderate temperatures. Int J Environ Sci Technol 17: 27-38.

171. H Jiang, S Luo, X Shi, M Dai, R Guo (2013) A system combining microbial fuel cell with photobioreactor for continuous domestic wastewater treatment and bioelectricity generation. J Cent South Univ 20: 488-494.

172. Z Yang, H Pei, Q Hou, L Jiang, L Zhang, (2018) Algal biofilm-assisted microbial fuel cell to enhance domestic wastewater treatment: Nutrient, organics removal and bioenergy production. Chem Eng J 332: $277-285$

173. Y Park, VK Nguyen, S Park, J Yu, T Lee (2018) Effects of anode spacing and flow rate on energy recovery of flat-panel air-cathode microbial fuel cells using domestic wastewater. Bioresour Technol 258: 57-63.

174. NJ Koffi, S Okabe (2020) Domestic wastewater treatment and energy harvesting by serpentine up-flow MFCs equipped with PVDF-based activated carbon air-cathodes and a low voltage booster. Chem Eng J 380: 122443.

175. S Bouatra, F Aziat, R Mandal, AC Guo, MR Wilson, et al. (2013) The Human Urine Metabolome. PLoS One 8(9): e73076.

176. SG Barbosa, L Peixoto, A Ter Heijne, P Kuntke, MM Alves, et al. (2017) Investigating bacterial community changes and organic substrate degradation in microbial fuel cells operating on real human urine. Environ Sci Water Res Technol 3: 897-904.

177. C Santoro, I Ieropoulos, J Greenman, P Cristiani, T Vadas, et al. (2013) Power generation and contaminant removal in single chamber microbial fuel cells (SCMFCs) treating human urine. Int J Hydrogen Energy 38(26): 11543-11551.
178. CA Cid, A Stinchcombe, I Ieropoulos, MR Hoffmann (2018) Urine microbial fuel cells in a semi-controlled environment for onsite urine pre-treatment and electricity production. J Power Sources 400: 441448.

179. Mohajit, KK Bhattarai, EP Taiganides, BC Yap (1989) Struvite deposits in pipes and aerators. Biol Wastes 30(2): 133-147.

180. KP Fattah (2012) Int J Environ Sci Dev.

181. NO Nelson (2000) Phosphorus removal from anaerobic swine lagoon effluent as struvite and its use as a slow-release fertilizer. North Carolina State University.

182. EV Münch, K Barr (2001) Controlled struvite crystallisation for removing phosphorus from anaerobic digester sidestreams. Water Res 35(1): 151-159.

183. GL Zang, GP Sheng, WW Li, ZH Tong, RJ Zeng, et al. (2012) Nutrient removal and energy production in a urine treatment process using magnesium ammonium phosphateprecipitation and a microbial fuelcell technique. Phys Chem Chem Phys 14: 1978-1984.

184. L Xiao, EB Young, JA Berges, Z He (2012) Integrated PhotoBioelectrochemical System for Contaminants Removal and Bioenergy Production. Environ Sci Technol 46(20): 11459-11466.

185. B Virdis, K Rabaey, RA Rozendal, Z Yuan, J Keller (2010) Simultaneous nitrification, denitrification and carbon removal in microbial fuel cells. Water Res 44(9): 2970-2980.

186. I Merino Jimenez, V Celorrio, DJ Fermin, J Greenman, I Ieropoulos (2017) Enhanced MFC power production and struvite recovery by the addition of sea salts to urine. Water Res 109: 46-53.

187. J You, J Greenman, C Melhuish, I Ieropoulos (2016) Electricity generation and struvite recovery from human urine using microbial fuel cells. J Chem Technol Biotechnol 91(3): 647-654.

188. D Fangzhou, L Zhenglong, Y Shaoqiang, X Beizhen, L Hong (2011) Electricity generation directly using human feces wastewater for life support system. Acta Astronaut 68(9-10): 1537-1547.

This work is licensed under Creative

Commons Attribution 4.0 License

DOI:10.19080/IJESNR.2021.28.556242

\section{Your next submission with Juniper Publishers} will reach you the below assets

- Quality Editorial service

- Swift Peer Review

- Reprints availability

- E-prints Service

- Manuscript Podcast for convenient understanding

- Global attainment for your research

- Manuscript accessibility in different formats

( Pdf, E-pub, Full Text, Audio)

- Unceasing customer service

Track the below URL for one-step submission https://juniperpublishers.com/online-submission.php 